\title{
Phylogeography and character evolution of Euphorbia sect. Aphyllis subsect. Macaronesicae (Euphorbiaceae)
}

\author{
Laia Barres ${ }^{1 *}$, Mercè Galbany-Casals ${ }^{2}$, Andrew L. Hipp ${ }^{3}$, Julià Molero ${ }^{4}$ \&
} Roser Vilatersana ${ }^{1}$

1 Institut Botànic de Barcelona (IBB - CSIC - ICUB), Pg. del Migdia s.n., E-08038 Barcelona, Spain.

2 Unitat de Botànica, Dept. Biologia Animal, Biologia Vegetal i Ecologia, Facultat de Biociències, Universitat Autònoma de Barcelona, E-08193 Bellaterra, Spain.

3 The Morton Arboretum, 4100 Illinois Route 53, 60532 Lisle, U.S.A.

${ }^{4}$ Laboratori de Botànica, Facultat de Farmàcia i Ciències de l'Alimentació, Universitat de Barcelona, Avgda. Joan XXIII s.n., E-08028 Barcelona, Spain.

*Author for correspondence: laia.barres@gmail.com

\section{Abstract}

The Macaronesian species of Euphorbia sect. Aphyllis subsect. Macaronesicae are distributed in four of the five archipelagos of Macaronesia and two mainland enclaves in Portugal and Morocco. The aims of this study are to investigate the biogeographic history of this group with AFLP and cpDNA markers, and to identify taxonomic entities within subsect. Macaronesicae based on genetic data, characterize them morphologically and infer the evolution of their diagnostic characters based on the reconstruction of ancestral character states. A continuous spatial diffusion analysis of AFLP data implicated Tenerife (central Canary Islands) as the area of origin of the group, followed by colonization of other Canarian islands and other Macaronesian archipelagos. Two dispersal events back to the mainland were also inferred. Our phylogenetic network, neighbour-joining clustering and Structure analyses of AFLP data demonstrated that species are genetically well delimited and suggested that they may have originated from a combination of allopatric speciation at broad scales (among islands) and fine scales (within islands), or possibly sympatric ecological speciation followed by more recent inter-island dispersal events. Ancestral character state reconstructions of morphological characters suggested that the ancestor of subsect. Macaronesicae was adapted to arid or mesic habitats, and traits associated with adaptation to humid habitats were acquired later. The central Canary Islands harbour the highest species diversity of this group in the 
Archipelago, and the highest nuclear and plastid genetic diversity. With regards to taxonomy, phylogenetic analyses and neighbour-joining clustering analyses based on AFLPs showed two clearly differentiated genetic groups, sister to each other, which correspond to the E. atropurpurea and E. lamarckii complexes formerly recognised based on morphology. Euphorbia aphylla is recovered as sister to the rest of the species, supporting its exclusion from the two complexes. Euphorbia tuckeyana is excluded from the E. lamarckii complex.

\section{Keywords}

AFLP; ancestral character state reconstruction; Canary Islands; Macaronesia; spatial diffusion; $\operatorname{trnL}$-trnF

\section{Short title}

Phylogeography of Euphorbia subsect. Macaronesicae

\section{INTRODUCTION}

The Macaronesian biogeographic region comprises five volcanic archipelagos situated between $14.5^{\circ} \mathrm{N}$ and $39.5^{\circ} \mathrm{N}$ latitude in the Atlantic Ocean: the Azores, Canary Islands, Cape Verde, Madeira and Selvagen Islands (Sunding, 1979); and two related mainland enclaves, one on the Atlantic coast of Morocco (Sunding, 1979) and the other at Cape Espichel in Portugal (Pedro, 1942). The Macaronesian archipelagos, like all oceanic islands, are considered a model system to study speciation, migration and extinction processes (Whittaker \& Fernández-Palacios, 2007), due to their de novo origin after land emergence from the sea and their endemic species richness and diversity. The Macaronesian flora harbours high percentages of endemic plants, ranging from an estimated 13\% in Madeira and Selvagen Islands (Jardim \& Sequeira, 2008) to 40\% in the Canary Islands (Santos-Guerra, 1999).

Phylogenetic and phylogeographic studies of Macaronesian endemic plant groups have tested several speciation processes and have revealed several patterns of oceanic island colonization and diversification. Most Macaronesian endemic plant clades have originated from a single colonization event (e.g. Helfgott \& al., 2000), but some have originated from multiple colonization events (Park \& al., 2001; Fuertes-Aguilar \& al., 2002; Carine \& al., 2004; Martín-Bravo \& al., 2007; Díaz-Pérez \& al., 2008). Niche preemption has been hypothesized to explain a higher rate of diversification in monophyletic groups that trace back to a single colonization event than in groups with multiple 
colonization events (Silvertown \& al., 2005). Generally, colonization of islands from the mainland has been considered to be a one-way journey, but back-colonization to the mainland (boomerang events) have also been documented (e.g. Carine \& al., 2004). Diversification through adaptive radiation can be facilitated by heterogeneity of habitats (e.g. García-Maroto \& al., 2009). The role of vicariance and dispersal in the radiation of endemic plant groups has also been investigated (Sanmartín \& al., 2008).

Euphorbia L. sect. Aphyllis Webb \& Berthel. has been demonstrated to be monophyletic based on molecular genetic evidence (Barres \& al., 2011; Riina \& al., 2013), and two subsections are diagnosable using morphological characters (Molero \& al., 2002): subsect. Macaronesicae Molero \& Barres comprises the Macaronesian species, and subsect. Africanae Molero \& Barres comprises the east/south African and south Arabian species. Euphorbia tuckeyana Steud., endemic to Cape Verde, is sister to the rest of sect. Aphyllis (Barres \& al., 2011), but was still included in subsect. Macaronesicae based on morphological similarities (Riina \& al., 2013). Phylogenetic relationships within the two subsections were poorly resolved and incongruence between chloroplast and nuclear markers was detected, presumably due to hybridization and rapid diversification (Barres \& al., 2011).

The present study focuses on subsect. Macaronesicae, which comprises 11 species distributed in four of the five oceanic archipelagos in the Atlantic Ocean that constitute Macaronesia - the Canary Islands, Cape Verde, Madeira and Selvagen Islands - and in the two mainland enclaves (Fig. 1). These species are mostly semi-succulent dendroid shrubs but also include succulent "pencil-like" shrubs (E. aphylla Brouss. ex Willd.), and are often dominant in such Macaronesian communities as the cardonal-tabaibal, a Canarian xerophilous lowland shrub community.

Species of subsect. Macaronesicae have been suggested to have dispersed to Macaronesia at least twice (Barres \& al., 2011), one colonization giving rise to $E$. tuckeyana in Cape Verde, and the other clade arising from a common ancestor of the rest of the species present in the other archipelagos. Based on the phylogenetic reconstructions available to date, which showed little resolution and included only one individual per species, little more could be said on the diversification of the group, the colonization of the different archipelagos and islands, and the origin of the mainland populations. However, Barres \& al. (2011) hypothesized that diversification of the group entailed both allopatric speciation (speciation caused by reproductive isolation of populations due to geographic barriers among oceanic islands) and adaptive, ecological speciation 
103 (speciation caused by adaptation of populations to different habitats within islands).

104 Biogeographic questions such as the origins of the entire clade diversification and of the two mainland enclaves, and the direction of island colonization are still unresolved.

Molero \& al. (2002) defined two taxonomic complexes within subsect. Macaronesicae based on morphology and ecology (Table 1): the E. atropurpurea complex, comprising E. atropurpurea Brouss. ex Willd., E. bourgaeana J. Gay ex Boiss. and E. bravoana Svent.; and the E. lamarckii complex, comprising E. anachoreta Svent., E. berthelotii Bolle ex Boiss., E. lamarckii Sweet, E. pedroi Molero \& Rovira, E. piscatoria Aiton, E. regis-jubae J. Gay and E. tuckeyana. Euphorbia aphylla was not included in either of these two complexes, but it also belongs to subsect. Macaronesicae according to recent phylogenetic analyses (Barres \& al., 2011; Riina $\&$ al., 2013). In those studies, E. tuckeyana was excluded from the main clade composed of all species of the two complexes. Molecular markers used in Molero \& al. (2002) and Barres \& al. (2011) failed to confirm or reject the monophyly of each of these two complexes, presumably due to rapid radiation of the group and consequent low resolution of DNA sequences.

In the current study, we investigate population genetic structure and species boundaries using amplified fragment length polymorphism (AFLP) DNA fingerprinting data (Vos \& al., 1995), which often provides more detailed information on patterns of genetic variation than DNA sequence data (Meudt \& Clarke, 2007). We integrate the AFLP data with cpDNA and morphological data to reconstruct the history of island colonization and dispersal routes in Macaronesia, focusing on two questions: (i) Where did the lineage originate, and what is the pattern of diversification among islands and archipelagos? (ii) Are species from the mainland sister to the remainder of the taxa, or derived from archipelago lineages? In addition, our study aims to identify taxonomic entities within subsect. Macaronesicae based on genetic data, characterize them morphologically and infer the evolution of their diagnostic characters, based on the reconstruction of ancestral character states.

Sampling.- The study includes specimens from 35 populations of the 11 species of subsect. Macaronesicae (Fig. 1; Table 2). Fresh leaves from up to six individuals from each field locality were collected and dried in silica gel. Sampling was designed to represent the global distribution of all species (Table 2). Field localities of previously reported hybrid specimens (Molero \& Rovira, 2005a) and specimens with intermediate 
137 morphological characters newly detected in the field were not sampled. A voucher specimen from each locality is deposited at $\mathrm{BC}$ or $\mathrm{BCN}$ (Table 2).

DNA extraction, AFLP fingerprinting and plastid DNA sequencing.- Total

140 genomic DNA was extracted from $10 \mathrm{mg}$ of silica gel dried leaves using the commercial

141 NucleoSpin Plant kit (Macherey-Nagel GmbH \& Co. KG, Düren, Germany) following

142 the manufacturer's protocol. For the AFLP procedure, total genomic DNA was digested

143 using the restriction enzyme pair EcoRI / MseI. Nineteen selective primer pairs were

144 surveyed in three individuals of three different species of which four were selected

145 prioritizing maximum polymorphism and reproducibility of alleles scored: (1) EcoRI-

146 AAG / MseI-CTA, (2) EcoRI-AGC / MseI-CCA, (3) EcoRI-AGC / MseI-CTT, and (4)

147 EcoRI-ACA / MseI-CCA. We followed the AFLP protocol by Vos \& al. (1995) as

148 modified by Berres (2001). Selective amplifications were performed using the EcoRI

149 primer marked with the fluorescent dye 6-FAM. Fragment analyses were done with an

150 ABI PRISM 3730 capillary sequencer genetic analyzer (Applied Biosystems, Foster City,

151 CA, USA) in the Pritzker Laboratory of the Field Museum Chicago using a 6-carboxyl-

152 X-rhodamine (ROX) labeled internal lane standard (GeneFlo 625; CHIMERx, Madison,

153 WI, USA). Alignment, binning, and scoring of fragments between 60 and 500 bp were

154 performed with GeneMarker v1.85 (Softgenetics, State College, PA, USA).

155 Reproducibility was checked for each primer pair with 13 randomly chosen replicated

156 individuals from different species, and an error rate was calculated (Bonin \& al., 2004).

157 AFLP loci that were ambiguous, non-reproducible or scored as present for fewer

158 individuals than the error rate were excluded from the dataset. The final scoring was

159 exported as an absence/presence binary matrix.

160 To analyze the cpDNA markers, we selected the trnL intron and trnL-trnF spacer

161 because this region showed a large number of polymorphism in previous studies (Barres

$162 \&$ al., 2011). The PCR reactions were performed following Barres \& al. (2011). PCR

163 products were purified with ExoSAP-IT (USB Corp., Cleveland, Ohio, USA), and the

164 amplified DNA segments were sequenced using BigDye Terminator Cycle Sequencing

165 v3.1 (Applied Biosystems), following the manufacturer's protocol, at the University of

166 Florida ICBR Core Facility on an ABI 3730xl capillary sequencer (Applied Biosystems).

167 Nucleotide sequences were edited using BioEdit v7.0.5.3 (Hall, 1999) and were aligned

168 manually. A region of 97 positions from the original matrix was deleted because of its

169 ambiguous alignment. Up to four individuals per population were selected, obtaining a 
170 total of 158 sequences. One sequence for each haplotype was deposited in the Genbank database with accession numbers KT799781-793.

AFLPs analyses.- The AFLPs binary data matrix was used to calculate a pairwise 173 genetic distance matrix using Nei \& Li (1979) restriction site distances. We used 174 SplitsTree4 v4.11.3 (Huson \& Bryant, 2006) to construct split networks of the total 175 dataset with a neighbour-net (NN) algorithm using the absence/presence matrix. 176 Neighbour-joining (NJ) and UPGMA clustering analyses of the genetic distance matrix 177 were computed with Treecon v1.3b (Van de Peer \& De Wachter, 1994). Branch support was estimated with 2000 nonparametric bootstrap (BS) replicates using the same program. In the NJ analyses, the trees were rooted with E. tuckeyana, based on previous analyses (Barres \& al., 2011). A Principal Coordinate Analysis (PCO) was conducted with NTSYSPC v2.0 (Rohlf, 1997) for a dataset excluding the outgroup.

We carried out a Bayesian clustering method implemented in Structure v2.3.3

183 (Pritchard \& al., 2000) to identify genetically disjunct groups in the complete dataset (excluding E. tuckeyana). To answer our biogeographic questions, we also carried out additional partial clustering analyses of clades obtained in the NJ tree containing species distributed across several islands. For the analyses of E. aphylla, E. bourgaeana, and E. piscatoria we used a dataset that excluded the primer pair EcoRI-ACA / MseI-CCA to increase the number of specimens analysed (see Table 3). Analyses were conducted under an admixture model and allele frequencies correlated among individuals with no prior information on the individual's sampling location. This was not done for the E. lamarckii dataset that showed limited assignment power and for which we included the locprior option implemented in the Structure software (Hubisz \& al., 2009), using island as the location prior. Ten independent runs for each $K$ value were performed in all analyses. The number of groups $(K)$ was set from $K=1$ to $K=15$ for the complete dataset and from $K$ $=1$ to the maximum number of populations in the partial analyses (see Table 3). Initial

196 burn-in of $10^{5}$ generations was followed by $10^{6}$ additional Markov chain Monte Carlo 197 (MCMC) generations. To determine the optimal number of $K$, we used the $\Delta K$ approach 198 (Evanno \& al., 2005) using Structure Harvester v0.6.93 (Earl \& vonHoldt, 2012). Results 199 from different runs were summarized by Clumpp v1.1.2b (Jakobsson \& Rosenberg, 2007). Structure results were represented using Distruct v1.1 (Rosenberg, 2004).

We used a continuous spatiotemporal Bayesian approach (Lemey \& al., 2009) to reconstruct the spatial dynamics of subsect. Macaronesicae. This approach uses BEAST v1.8.2 (Drummond \& al., 2012) with a lognormal relaxed random walk (RRW) model, 
which is a time heterogeneous approach that allows for variation in diffusion rates across the branches of the phylogeny (Lemey \& al., 2009), to infer the geographic location of ancestors and the diffusion of lineages continuously in space and time while allowing for genealogical uncertainty. We ran two independent MCMC analyses of 100 million generations each, sampling every 10,000 trees with BEAST v1.8.2 using a simple substitution model with estimated state frequencies for phylogenetic inference. A Bayesian skyline coalescent prior with a piecewise-linear skyline model was set as the model of population growth. The diffusion process was modelled by a lognormal relaxed random walk process with a lognormal distribution centred on 1 . We specified a prior exponential distribution on the standard deviation of the lognormal distribution with a mean of five. We added random jitter with a window size of 1.0 to the tips, as several individuals from the same location were analysed. We used a strict molecular clock and evaluated MCMC mixture and convergence by requiring effective sample sizes (ESS) of at least 200 as estimated in Tracer v1.6.0 (Rambaut \& al., 2013). We combined trees obtained from the two independent runs with LogCombiner (part of the BEAST package) after removing $10 \%$ of trees as burn-in (as suggested by Tracer, and supported by ESS calculations of $>200$ ). A maximum clade credibility (MCC) tree was produced and summarized with TreeAnnotator (part of the BEAST package) and visualized in FigTree v1.4.2 (http://tree.bio.ed.ac.uk/software/figtree/). The MCC tree obtained under the diffusion model was analysed with the Continuous Tree module of SPREAD v1.0.6 (Bielejec \& al., 2011), and a visual representation of lineage diffusion over time and space was generated with Google Earth v6.0.1 (Google Inc.). SPREAD uses Bayes factors to evaluate the support for alternative hypotheses of historical diffusion among pairs of discrete locations based on Bayesian stochastic search variable selection estimates, accommodating the uncertainty of the original phylogenetic inference (Bielejec \& al., 2011), and maps phylogenies annotated with continuous spatial information also allowing to export the high-dimensional posterior summaries to keyhole markup language (KML). Visualization allows for generating maps at different times with the time slicer function, using light colours to indicate more ancient diffusion events and dark colours to indicate recent events.

To assess the distribution of genetic variation, analyses of molecular variance (AMOVA) were carried out based on Euclidean distances among samples using Arlequin v3.1 (Excoffier \& al., 2005) with 1000 random permutations. Different nested analyses were performed (Table 4). 
Analyses of haplotypes.- A statistical parsimony haplotype network was constructed with the cpDNA sequences using TCS v1.21 (Clement \& al., 2000). Indels were coded for this analysis using the simple coding algorithm (Simmons \& Ochoterena, 2000) implemented in the program SeqState v1.4.1 (Müller, 2005). Then, in the TCS analysis, indels were treated as missing data.

Phylogenetic analyses of the haplotypes were performed using maximum parsimony (MP) and Bayesian inference (BI) methods, implemented in the programs PAUP* v4.0b10 (Swofford, 2002) and MrBayes v3.2 (Ronquist \& Huelsenbeck, 2003), respectively. Six species from subsect. Africanae and one from sect. Pachycladae (Boiss.) Tutin were included as outgroups following Barres \& al. (2011). MP analyses used heuristic search with 1000 replicates of random taxon addition with mulpars in effect and tree-bisection-reconnection (TBR) branch swapping. All most parsimonious trees were saved. Parsimony uninformative positions were excluded. After the strict consensus tree was computed, a nonparametric bootstrapping analysis (Felsenstein, 1985) was performed following Lidén \& al. (1997), using 1000 replicates of heuristic search, 10 random taxon additions with 10 replicates per each BS replicate, multrees option not in effect, and no branch swapping.

The Akaike information criterion (Akaike, 1973), as implemented in MrModeltest v2.3 (Nylander, 2004), was used to select the best-fit model of substitution (GTR for the sequence partition and F81 for the indel partition). Two independent analyses of four Metropolis-coupled Markov chains were run for five million generations in MrBayes, saving one of every 500 trees until they reached stationary frequencies (final split frequency between the two runs, $\mathrm{P}<0.01)$. A $50 \%$ majority rule consensus tree was computed from the posterior distribution after discarding the first $25 \%$ of trees as burnin.

Analyses of character evolution.- Ancestral character state reconstructions for morphological characters were performed with Mesquite v2.74 (Maddison \& Maddison, 2010). Species were represented by one terminal individual except for E. regis-jubae, for which two individuals were retained due to polymorphism in the Moroccan populations. Euphorbia tuckeyana was excluded from the analyses because the lack of members of subsect. Africanae could bias the results (see Barres \& al., 2011). Maximum Likelihood (ML) was used to reconstruct the evolution of six selected characters on a $\mathrm{NJ}$ tree inferred from Nei and Li distances calculated with PAUP from the AFLP data under the singlerate $(\mathrm{Mk} 1)$ model. Discrete characters used for ancestral state reconstruction were 
selected because they are diagnostic of the two complexes previously recognized within

273 the subsection (Table 1), diagnostic of a taxon (like subtruncate nectaries for $E$. 274 bourgaeana, rugose seed surface for E. piscatoria, scrobiculariate seed surface for $E$. 275 bravoana or mitriform caruncle and obnavicular-elongate caruncle for E. pedroi), or 276 diagnostic of a regional group of populations within a taxon (horned nectaries for the 277 Canarian populations of E. regis-jubae). Characters and their states were defined as 278 follows: A. pleochasial organization (of the sympodial synflorescence branching pattern: 279 simple, 0; double, 1); B. nectaries morphology (truncate, 0; subtruncate, 1; dentate, 2; 280 horned, 3); C. sub-cyathial bracts persistence (deciduous before fructification, 0; deciduous just after fructification, 1; persistent, 2); D. sub-cyathial bracts union (free, 0; connate, 1); E. seeds surface (smooth-rugulose, 0; rugose, 1; excavate, 2; scrobiculariate, 3); F. caruncle morphology (obnavicular-truncate, 0; obnavicular-elongate, 1; mitriform, 2). Additionally, some of these attributes are related to ecological preferences and were specifically used to interpret the adaptation of the ancestral populations to the environment during the colonization of Macaronesia. These are double pleochasium and connate, persistent bracts, which imply the maintenance of large foliar structures during all year, contrary to the strategy adopted by drought tolerant species, which have small and/or deciduous leaves, in order not to lose water by evapotranspiration. Information on all the character states studied was obtained from our own observations and from the literature (Boissier, 1862; Press \& Short, 1994; Molero \& Rovira, 1996; 1998; Benedí \& al., 1997; Bramwell \& Bramwell, 2001; Molero \& al., 2002; Acevedo \& al., 2003; Mesa \& al., 2007; Mesa, 2009).

\section{RESULTS}

296 AFLP analyses. - A total of 346 bands were scored for 189 individuals, of which 332 297 (95.95\%) were polymorphic. The AFLP replicates we performed showed a genotyping 298 error rate of $1.16 \%$ which we considered negligible in a study of this scale. Three fixed 299 private alleles were found, one in E. anachoreta and two in E. bravoana. The NN diagram 300 produced (Fig. 2) is highly congruent with the results obtained with NJ (Fig. 3), showing 301 species as monophyletic with BS support between $78 \%$ and $100 \%$ (Fig. 3), except for $E$. regis-jubae. This species was recovered as paraphyletic, with a clade composed of all samples of E. pedroi embedded in it $(\mathrm{BS}=100 \%)$. Three main clusters were recovered (Fig. 3): the first included all populations of E. aphylla supported with $100 \% \mathrm{BS}$, the second included all species from the E. atropurpurea complex (E. atropurpurea, E. 
bravoana and $E$. bourgaeana) with $94 \%$ of BS, and the third included all species from the E. lamarckii complex (E. anachoreta, E. berthelotii, E. lamarckii var. lamarckii, E. lamarckii var. broussonetti (Willd. ex Link) Molero \& Rovira, E. pedroi, E. piscatoria and E. regis-jubae), except for E. tuckeyana, with 95\% BS support. Euphorbia tuckeyana populations were grouped in a non-supported clade (Figs. 2 and 3). The same results were recovered with the UPGMA tree (not shown). In the PCO analysis (Electr. Suppl.: Fig. S1), $21.50 \%$ of the variability was explained by the first axis, $17.67 \%$ by the second axis and $11.65 \%$ by the third axis, for a sum of $50.84 \%$ of the total variability. The specimens were grouped in a similar way as in the NN analysis (Fig. 2). In the Structure analyses of the whole dataset excluding E. tuckeyana, the optimal value of $K$ was seven (Fig. 4A; Table 3). The green group was found in E. lamarckii, which is in general genetically uniform and in E. anachoreta; the yellow group was mainly found in the group composed by E. regis-jubae and E. pedroi but also in E. anachoreta and E. bravoana; the brown group was mainly found in E. aphylla but also in E. bravoana; the pink group was mainly found in the genetically uniform E. atropurpurea but also in E. bravoana and $E$. lamarckii; the blue group was mainly found in E. berthelotii but also in E. aphylla and E. bravoana; the orange group was mainly found in the genetically uniform E. piscatoria but also in E. berthelotii. The red group corresponded to E. bourgaeana. The partial Structure analyses of clades analysed showed the following results: for E. bourgaeana the optimal number of groups was three (Fig. 4B; Table 3); the first group (green group) included all populations from La Gomera; the second group (light blue group) included one population from west Tenerife (mauve group) and the third group included two populations from east Tenerife. Another population of west Tenerife showed a high level of genetic admixture of the mauve and the light blue groups (Fig. 4B). Euphorbia lamarckii and E. anachoreta were clearly recovered as two different entities (Table 3; Figure not shown). Considering this result, and also the results of all previous analyses (Figs. 2 and 3; Electr. Suppl.: Fig. S1), we only performed the Structure analyses of the most widely distributed species, E. lamarckii. This showed an optimal number of $K=4$ (Fig. 4C; Table 3), with three different groups geographically structured (the pink group was only present in Tenerife, the blue group was present in La Gomera and Tenerife, and the orange group was present in La Palma and El Hierro; Fig. 4C) and one group scattered in few individuals from La Gomera and Tenerife (green colour, Fig. 4C). The Structure analysis detected two genetic groups as the optimal $K$ for E. piscatoria (Fig. 4D), which 
340 individual from Porto Santo that was assigned to the Madeiran main island population, 341 and two additional individuals from Porto Santo that showed mixed ancestry of the two 342 groups. In the E. tuckeyana partial analysis, four genetic groups were recovered. The 343 green group characterized all individuals from the southern islands populations (Fogo and 344 Santiago) but it is also present in a much lesser degree in all the specimens from other 345 islands. The salmon group characterizes the only two specimens from São Vicente, which 346 are genetically almost uniform, but this group is also present in other specimens, 347 especially from Fogo. The orange group is especially represented in all the specimens 348 from São Nicolau, but is also found in some specimens from Fogo and Santiago. Finally, 349 the blue group characterizes all the specimens from Santo Antão, which are genetically 350 almost uniform, but this group is also present in few individuals from all the other islands 351 (Fig. 4E). The analyses of the cluster E. regis-jubae + E. pedroi (Fig. 4F; Table 3) 352 recovered two groups, one found mainly in the Gran Canarian populations of E. regis353 jubae (green group) and the other present in all populations of both species with a little level of mixture with some individuals from Gran Canaria island (purple group). Finally, one group (no population structure) was detected for E. aphylla (Table 3).

Spread diffusion analyses argue for an origin of diversification in Tenerife (Canary Islands, Fig. 5A), followed by several dispersal events to other Canarian Islands and Madeira (Fig. 5B). A first back-colonization of the mainland by a dispersal event from the east Canarian Islands (Fuerteventura and Lanzarote) to Morocco gave rise to the mainland E. regis-jubae populations (Fig. 5C). A second back-colonization of the mainland by an independent dispersal event from the east Canarian Islands to Portugal resulted in the origin of E. pedroi. Finally, E. anachoreta arose from the colonization of Selvagen Islands from Tenerife (Fig. 5D). $\phi$ ST values obtained ranged from 0.32 to 0.84 (Table 4).

Analyses of haplotypes.- We detected 13 haplotypes that differed from each other by one to six substitutions (Fig. 6). The relationships among these haplotypes are shown in Fig. 6B. Four haplotypes were shared among different species (Fig. 6A; Table 2). The most common haplotype was IV, present in 25 populations of nine species, and was the only haplotype sampled in E. anachoreta, E. bravoana, E. pedroi and E. regisjubae. Six haplotypes were exclusive for one population (III, V, VII, X, XI and XIII). Euphorbia lamarckii exhibited the greatest haplotype diversity of any species (five haplotypes). The three populations of E. atropurpurea showed three different haplotypes. The populations of E. aphylla showed the same haplotype in Tenerife and La Gomera but 
374 the population of Gran Canaria had an additional haplotype. In E. bourgaeana, more 375 cpDNA differences were found between populations within Tenerife than between 376 populations from Tenerife and La Gomera. The islands of Gran Canaria, Tenerife and La 377 Gomera (central Canary Islands) presented a higher number of different haplotypes (11) 378 than the western Canary Islands (three haplotypes) or the eastern Canary Islands + the mainland (Portugal and Morocco), where only one haplotype was found. Phylogenetic analyses of cpDNA resulted in low resolution (Electr. Suppl.: Fig. S2). The only supported clade included three haplotypes (I, II and III), which are present in the southern population of E. atropurpurea, most populations of E. lamarckii and one individual of E. piscatoria.

Analyses of character evolution.- The ancestral state for pleochasial organization was inferred to be simple, with acquisition of double organization in the $E$. atropurpurea complex (Fig. 7A). For nectary morphology, the ancestral state was reconstructed to be truncate. Dentate nectaries were inferred to have appeared twice independently: in E. piscatoria and with some ambiguity in the ancestor of the E. pedroi + E. regis-jubae, which was inferred to have dentate, horned or truncate nectaries with the same probability (Fig. 7B). Subtruncate nectaries are an autopomorphy of $E$. bourgaeana and horned nectaries are an autopomorphy of the Canarian populations of $E$. regis-jubae. The sub-cyathial bracts appear to have been ancestrally deciduous before fructification (Fig. 7C). Under this reconstruction, the ancestor of the E. atropurpurea complex would have acquired persistent sub-cyathial bracts secondarily, and some members of the E. lamarckii complex would have shifted to deciduous bracts just after fructification. Free sub-cyathial bracts were inferred as ancestral, with a shift to connate bracts in the E. atropurpurea complex (Fig. 7D). Seed surface was reconstructed to be smooth-rugulose in the ancestor of subsect. Macaronesicae. Rugose seeds are an autopomorphy of E. piscatoria, and excavate seeds were inferred to appear in the ancestor

400 of the E. atropurpurea complex (Fig. 7E). Euphorbia bravoana was reconstructed to have 401 later acquired scrobiculariate seeds as an autopomorphy. The obnavicular-truncate 402 caruncle was inferred to be the ancestral condition for caruncle morphology (Fig. 7F). 403 Two later shifts were reconstructed: one to obnavicular-elongate state in E. pedroi and 404 the other to mitriform state in E. atropurpurea.

\section{DISCUSSION}



suggest that the clade originated in Tenerife, from which the group diversified by several dispersal to nearby islands and archipelagos (Fig. 5). These dispersals and resultant

410 allopatry produced numerous single-island endemic species during the early 411 diversification of the group. Subsequent inter-island dispersal has contributed to range 412 expansion of several species that range across two or more islands. The high inter-island 413 migration of subsect. Macaronesicae is attributable to numerous stochastic dispersal 414 vectors: wind, driftwood, and endozoochory by birds, given that rock pigeons (Columba 415 livia canariensis Bannerman) and migratory turtle doves (Streptopelia turtur turtur L.) have been recorded as Euphorbia seed feeders (Nogales, 1985; Berg, 1990). Inter-archipelago dispersal.- Contrary to other Macaronesian endemic plant groups such as Argyranthemum Webb, for which a dispersal route north to south in the Madeira-Desertas-Selvagen Islands has been proposed (Francisco-Ortega \& al., 1996), our study reveals a northward dispersal from the Canary Islands to Madeira Archipelago, as shown by the spatial diffusion analysis (Fig. 5B). One of the first dispersals of the group from Tenerife resulted in the origin of E. piscatoria in Porto Santo (age: 14.3 Ma; Geldmacher \& Hoernle, 2000; Fig. 5B), and from there this species later colonized Madeira (age: 4.6 Ma; Geldmacher \& Hoernle, 2000). In the past, the trade winds associated with the presence of higher mountains in earlier developmental stages of Porto Santo may have favoured the existence of more mesic habitats (Fernández-Palacios \& al., 2011) and establishment of the ancestor of E. piscatoria. This species acquired two morphological characters after the colonization of this archipelago and the isolation from its ancestor: dentate nectaries and rugose seeds (Figs. 7B, 7E). Euphorbia piscatoria 430 populations from both islands may have been isolated for a long time, as they exhibit strong geographic structure between Madeira and Porto Santo (Figs. 2-4; Electr. Suppl.:

432 Fig. S1), except for one individual from Roche de Nossa Senhora in Porto Santo which is 433 grouped with the specimens from Madeira (PIS34; Fig. 4D). Placement of this single 434 individual might be due to lab error or recent establishment of seeds from Madeiran 435 specimens in Porto Santo. Porto Santo populations are scarce and especially threatened 436 by fragmentation of natural habitats and introduced grass-feeding animals (Faria \& al., 437 2008). In either case, to conserve genetic diversity within E. piscatoria, our data support 438 recognition of two Evolutionary Significant Units (ESU; Moritz, 1994) in the two 439 different islands. Further studies regarding this species should include populations from 
440 the Desertas Islands, $25 \mathrm{~km}$ disjunct, to understand their genetic affinities and possible origin.

Colonization of the Selvagen Islands, an archipelago of islets that originated 12

443 Ma (Bogaard, 2013), is inferred to have occurred by dispersal from Tenerife (Fig. 5D)

444 before the arrival to Morocco or to the older Madeira (14.3 Ma; Geldmacher \& Hoernle,

445 2000). Euphorbia anachoreta, an endemic from Ilhéu de Fora islet in the Selvagen

446 Archipelago, originated by allopatric differentiation from a shared common ancestor with

447 E. lamarckii (Fig. 4A) from Tenerife. Although we only included three E. anachoreta 448 individuals in the analyses, this represents about $12 \%$ of the single population of this 449 species (Carvalho, personal communication), which is among the 100 most threatened 450 species in Macaronesia (Jardim \& al., 2008).

Back-colonization to the mainland.- Back-dispersal events of Macaronesian organisms to the mainland have been reported for several plant groups (Mes \& Hart, 1996; Park \& al., 2001; Carine \& al., 2004). During the Quaternary glaciations, Macaronesian islands acted as a biodiversity refuge, providing a source of genetic diversity that later have contributed to mainland biodiversity (Patiño \& al., 2015). An exchange of flora between Macaronesia and the Atlantic coasts of the African and European continents could have occurred repeatedly in the Quaternary during glacial times, when volcanic marine seamounts emerged and could have acted as stepping stones facilitating the arrival of several species at the mainland (García-Talavera, 1997; Fernández-Palacios \& al., 2011). As shown by the spatial diffusion analysis, back-colonization to the mainland from the eastern Canary Islands explains the presence of E. regis-jubae on the Atlantic coast of Morocco (Fig. 5C). Ecological conditions in Fuerteventura and Lanzarote have been similar to those on the west coast of Morocco since the Pliocene (Caujapé-Castells, 2011), favouring this establishment.

An independent back-colonization event from the eastern Canary Islands to Portugal gave rise to E. pedroi (Fig. 5D), probably through the same dispersal pattern and at approximately the same time as the origin of the Moroccan populations of E. regisjubae. The presence of other several plant species (e.g. Convolvulus fernandesii Pinto da Silva and Teles, Davallia canariensis (L.) Sm., Woodwardia radicans (L.) Sm.) with related lineages having a disjunct distribution in Macaronesia and Cape Espichel and nearby mountains such as Serra da Arrábida and Serra de Sintra reinforces the consideration of this area of Portugal as a second mainland Macaronesian enclave. The influence of trade winds maintaining similar climate conditions would have facilitated 
the establishment and permanence of these lineages. AFLP analyses (Figs. 2-4; Electr.

475 Suppl.: Fig. S1) suggest that E. pedroi -which is recovered as a monophyletic entity 476 embedded in a paraphyletic E. regis-jubae - could have originated by peripatric speciation 477 (founder effect; Futuyma, 2005) from the more widely distributed and genetically more 478 diverse E. regis-jubae. Euphorbia pedroi and the Moroccan populations of E. regis-jubae 479 share a common character, dentate nectaries, which is inferred to be most probably 480 present in their common ancestor from the Canary islands (Fig. 7B). The relatively low genetic diversity in the E. regis-jubae - E. pedroi complex (Fig. 6; Table 2) suggest a very recent origin of this group. Biased allele frequencies caused by the new population establishment by a few individuals often produces rapid genetic and morphological differentiation from the original populations by genetic drift (Futuyma, 2005). Indeed, $E$. pedroi is morphologically readily distinguishable from E. regis-jubae by its extremely elongate seed caruncle (Fig. 7F) and dentate nectaries (Fig. 7B) sometimes showing horns up to $0.3 \mathrm{~mm}$ long (in the Canarian E. regis-jubae these horns are $0.3-1 \mathrm{~mm}$ long). As the analysis of ancestral states shows, this type of caruncle would have developed after the colonization of Portugal, given that it is not inferred for the common ancestor of $E$. pedroi and E. regis-jubae (Figs. 7B and 7F). Because of its morphological distinctness, monophyly found in the NN and the NJ analyses (Figs. 2 and 3), and geographical isolation, we recommend maintaining E. pedroi as a separate species.

Euphorbia tuckeyana.- This species from Cape Verde was recovered as an independent clade from the rest of species from subsect. Macaronesicae (Barres \& al., 2011). Results from the AFLP and the cpDNA analyses here performed confirm its independent origin as it is genetically isolated from the other species (Figs. 2, 3 and 6). With regards to the geographic structure of genetic variation inferred from the AFLP, a notable degree of admixture of most populations is observed (Fig. 4E). These results, the low cpDNA variation (Fig. 6), and the lack of further speciation in this archipelago, may suggest a recent colonization of the archipelago and recent divergence between populations from different islands, or alternatively the existence of gene flow between them. However, despite the genetic admixture, the four genetic groups detected by Structure show some degree of geographic structure: in populations from the southern islands (Fogo and Santiago) the predominant group is the green one, whereas in populations from the northern islands (Santo Antão, São Vicente and São Nicolau) the other three groups predominate. Similar patterns of genetic differentiation of northern 
$508 \&$ al., 2015), and this pattern has also correspondence with two of the main floristic or

509 phyoteographic elements defined by Brochmann \& al. (1997) for Cape Verde, who

510 classified the islands in three main groups (see Fig. 1): the northern islands (Santo Antão,

511 São Vicente and São Nicolau), the eastern islands (Maio, Sal and Boa Vista) and the

512 Southern islands (Brava, Fogo and Santiago). The eastern islands, where E. tuckeyana is

513 only found in Sal, were not represented in our study.

514 General patterns of diversification and genetic variation in the Canary

515 Islands. - The central Canary Islands and specifically Tenerife were shown to be the 516 centre of origin of the group (Fig. 5A), agreeing with the Sanmartín \& al. (2008) model.

517 The central Canary Islands harbour the highest diversity in the Archipelago. This can be

518 explained as a consequence of the topological, climatic and habitat heterogeneity of these

519 islands (Caujapé-Castells, 2011). Seven of the eight Canarian species (87.5\%) of subsect.

520 Macaronesicae are found in the central Canary Islands, three of them being endemics to

521 Tenerife. Species from the central and western islands also show stronger inter-population

522 nuclear genetic differentiation (Fig. 4), and a higher number of haplotypes (nine) was

523 detected in the central islands than in the eastern islands and on the mainland (one; Fig.

524 6A). Most of the central-western island species (E. atropurpurea, E. bourgaeana and E.

525 lamarckii), including the single-island endemic E. atropurpurea show striking

526 intraspecific haplotype diversity, suggestive of incipient population differentiation (Fig.

527 6A). These observations and the coexistence of ecologically different species on some of

528 the islands suggest that fine scale allopatric speciation or sympatric speciation due to

529 ecological differentiation may have played a role in the differentiation of this group of 530 species.

531 In contrast, despite the proximity to the mainland and the older age of the eastern 532 group of islands, the total number of Macaronesian endemic species in these islands is 533 lower than in the rest (Reyes-Betancort \& al., 2008). In accordance with this pattern, there 534 is only one subsect. Macaronesicae eastern islands endemic, E. regis-jubae, which 535 presents a low level of inter-population genetic differentiation (Figs. 4F and 6). The flat 536 topology and the ecological homogeneity of these islands could have allowed gene flow 537 between populations, eroding any genetic differentiation of possibly distinct colonizing 538 genotypes which previously had been isolated on the mainland (Caujapé-Castells, 2011).

539 In the eastern populations, genetic variation is noticeably higher within than between 540 populations (Table 4). 
Systematic considerations. - Although the radiation of the group is hypothesised

542 to have been relatively recent (Barres \& al., 2011), there have been time and isolation 543 enough to generate genetic differentiation between species and maintain them as 544 genetically isolated and morphologically distinguishable entities. The combination of 545 AFLP and cpDNA markers together with previous morphological data allow us to provide 546 some insights on the systematics of the group.

We propose to exclude E. tuckeyana from the E. lamarckii complex considering 548 its independent origin already detected in a previous work (Barres \& al., 2011) and its 549 current genetic isolation, evidenced by both the AFLP (Figs. 2 and 3) and cpDNA analyses (Fig. 6).

Euphorbia aphylla, a fleshy aphyllous pencil-like shrub found in saline habitats in the central Canary Islands, was resolved as sister to the rest of subsect. Macaronesicae ingroup with 100\% BS support in the NJ analyses (Fig. 3), in agreement with Molero \& al.'s (2002) taxonomic treatment, that excluded this species from the two main taxonomic complexes recognized in the group based on morphology. The isolation of E. aphylla from the rest is confirmed by the haplotype network, as it has two different exclusive haplotypes (IX and X; Fig. 6A). We found no genetic differentiation within the populations of E. aphylla (not shown), although it grows on three different islands of the Canarian archipelago (Fig. 1).

The AFLP analyses supported the two taxonomic complexes (Figs. 2 and 3; Electr. Suppl.: Fig. S1) as sister clades with strong BS support (BS = 95\%; Fig. 3). Both complexes are genetically differentiated and some of the morphological differences between them may be ecological adaptations (Fig. 7A, C, D; Table 1). Species from the E. lamarckii complex, as well as E. aphylla, are adapted to arid and mesic habitats not affected by trade winds, such as pine forest and arid lowland scrub in Madeira and the

566 Canary Islands, and the two mainland enclaves in Morocco and Portugal. They have free, deciduous bracts (Fig. 7C, D) and a simple synflorescence (Fig. 7A), which are reconstructed as the ancestral condition for the E. lamarckii complex and for the whole subsect. Macaronesicae and in our analyses. These structures would contribute to reduce water loss in the dry season, and would have allowed the establishment in similar habitats when the group first colonized the islands. Species from the E. atropupurea complex, on the other hand, are found in mesic to humid habitats affected by trade winds where laurel forests grow in Tenerife and La Gomera. They have double synflorescences (Fig. 7A) and connate, semi-persistent bracts (Fig. 7C, D), as they do not need to save water by reducing 
575 their structures. These traits, as inferred by our analyses, would have been acquired secondarily by the common ancestor of this complex, together with excavate seeds instead of smooth-rugulose seeds (Fig. 7E). Plastid DNA markers showed very low resolution

578 (Electr. Suppl.: Fig. S2) but the only supported clade contained E. atropurpurea and E. lamarckii, belonging to the two different taxonomic complexes recognized in all AFLPs analyses. This incongruence supports the hypothesis of introgression by the maternal lineage as suggested by Barres \& al. (2011).

Euphorbia bourgaeana shows strong genetic differentiation between La Gomera and Tenerife (Fig. 4B), presenting the highest $\phi$ ST values $(0.83$; Table 4$)$ in our study, in accordance with their geographic isolation. Populations from La Gomera were considered an independent species, E. lambii Svent., in the past (Sventenius, 1960). However, the degree of genetic differentiation of E. lambii from populations of Tenerife is not higher than that found between genetic groups detected within Tenerife (Fig. 4B; Table 4), and more cpDNA differences were found between populations within Tenerife than between populations from Tenerife and La Gomera (Fig. 6). The higher genetic variation found within the whole of E. bourgaeana and especially within Tenerife and the lack of a clear pattern of macro- and micromorphological differentiation between the two island groups of populations (Molero \& Rovira, 2005b; Molero, Barres \& Rovira, in prep.) suggest that E. lambii should be considered part of the variation of E. bourgeana. In terms of conservation, we recommend the recognition of three different ESUs (Moritz, 1994) for the vulnerable E. bourgaeana species (Bañares \& al., 2010): one in La Gomera and two in east and west Tenerife, corresponding with the two main genetic groups detected in this island. Recognizing three ESUs (Moritz, 1994) in this species would help to preserve its total genetic diversity and guide conservation strategies.

\section{Acknowledgments}

The authors gratefully acknowledge Ricardo Mesa, Juan Matos, Jordi López-

602 Pujol, Francisco Zamora, Ángel Fernández López, Aurelio Acevedo, Rafael Rodríguez 603 de Paz and José Augusto Carvalho for their assistance in the fieldwork. Special thanks go 604 to Gobierno de Canarias - Consejería de Medio Ambiente y Ordenación Territorial for 605 their permits to collect species on the Spanish Red List. Also thanks to Parque Nacional 606 de Garajonay, Cabildo Insular de Tenerife, Cabildo Insular de La Gomera, Cabildo 607 Insular de La Palma and Cabildo Insular de El Hierro for their authorization to collect 608 plants and to Jardím Botánico da Madeira for providing material from Selvagen Islands. 
609 Alka Srivastava, Jaime Weber, Kyong-Sook Chung and Marcial Escudero provided 610 useful and pleasant laboratory assistance, and Kevin Feldheim and staff of The Pritzker 611 Lab provided invaluable support. Pau Carnicero-Campmany and Henrique Batalha-Filho 612 helped with the Spread analysis. Constructive criticism from the anonymous reviewers 613 and the editors contributed to improve the manuscript. This study was supported by the 614 Ministry of Education and Science, Spanish Government (project CGL2010-18631/BOS, 615 CGL2009-13322-C03-03, MEC-CSIC (200730i1035) and BES-2007-14260 (Ph.D. grant 616 to L. Barres) and the Catalan Government ('Ajuts a grups consolidats' 2009/SGR/00439 617 and 2014/SGR/514).

618

\section{Literature cited}

620

621 Acevedo, A., Rodríguez, A., Rodríguez, B. \& Hernández, A. 2003. Chorology of 622 Euphorbia bourgeauana Gay ex Boiss. in DC. in Teno massif (Tenerife, Canary Islands) 623 (Euphorbiaceae). Vieraea 31: 45-50.

624 Akaike, H. 1973. Information theory and an extension of the maximum likelihood 625 principle. Pp. 267-281 in: Petrov, B.N. \& Csáki, F. (eds.), Second International 626 Symposium on Information Theory. Budapest: Akadémiai Kiadó.

627 Bañares, Á., Blanca, G., Güemes, J., Moreno, J.C. \& Ortiz, S. (eds.). 2010. Atlas y 628 Libro Rojo de la flora vascular amenazada de España. Adenda 2010. Madrid: Dirección 629 General de Medio Natural y Política Forestal (Ministerio de Medio Ambiente, y Medio 630 Rural y Marino) - Sociedad Española de Biología de la Conservación de Plantas.

631 Barres, L., Vilatersana, R., Molero, J., Susanna, A. \& Galbany-Casals, M. 2011. 632 Molecular phylogeny of Euphorbia subg. Esula sect. Aphyllis (Euphorbiaceae) inferred 633 from nrDNA and cpDNA markers with biogeographic insights. Taxon 60: 705-720.

634 Benedí, C., Molero, J., Simon, J. \& Vicens, J. 1997. Euphorbia L. Pp. 210-285 in: 635 Castroviejo, S., Laínz, M., López-González, G., Montserrat, P., Muñoz-Garmendia, F., 636 Paiva, J. \& Villar, L. (eds.), Flora Iberica, vol. 8. Madrid: Real Jardín Botánico de 637 Madrid, CSIC.

638 Berg, R.Y. 1990. Seed dispersal relative to population structure, reproductive capacity, 639 seed predation, and distribution in Euphorbia balsamifera (Euphorbiaceae), with a note 640 on sclerendochory. Sommerfeltia 11: 35-63. 
641 Berres, M. 2001. General fluorescent AFLP (fAFLP) protocols. University of Wisconsin 642 Department of Zoology. http://ravel.zoology.wisc.edu/sgaap/AFLP 643 _html/fAFLP_protocols.htm (accessed 30 Sep 2002).

644 Bielejec, F., Rambaut, A., Suchard, M.A. \& Lemey, P. 2011. SPREAD: spatial 645 phylogenetic reconstruction of evolutionary dynamics. Bioinformatics 27: 2910-2912. 646 http://dx.doi.org/10.1093/bioinformatics/btr481

647 Bogaard, van den P. 2013. The origin of the Canary Islands seamount province - new 648 ages of old seamounts. Scientific reports 3: 2107. http://dx.doi.org/10.1038/srep02107

649 Boissier, P.E. 1862. Euphorbiaceae subordo Euphorbieae. Pp. 3-188 in: Candolle, A.P. 650 de (ed.), Prodromus systematis naturalis regni vegetabilis, vol. 15. Paris: Treuttel \& 651 Würtz.

652 Bonin, A., Bellemain, E., Eidesen, P.B., Pompanon, F., Brochmann, C. \& Taberlet, 653 P. 2004. How to track and assess genotyping errors in population genetics studies. Molec.

654 Ecol. 13: 3261-3273. http://dx.doi.org/10.1111/j.1365-294X.2004.02346.x

655 Bramwell, D. \& Bramwell, Z.I. 2001. Flores silvestres de las islas Canarias. Madrid: 656 Editorial Rueda.

657 Brochmann, C., Rustan, Ø.H., Lobin, W. \& Kilian, N. 1997. The endemic vascular 658 plants of the Cape Verde Islands, W. Africa. Sommerfeltia 24: 1-356.

659 Carine, M.A., Russell, S.J., Santos-Guerra, A. \& Francisco-Ortega, J. 2004. 660 Relationships of the Macaronesian and Mediterranean floras: Molecular evidence for 661 multiple colonizations into Macaronesia and back-colonization of the continent in 662 Convolvulus (Convolvulaceae). Amer. J. Bot. 91: 1070-1085. 663 http://dx.doi.org/10.3732/ajb.91.7.1070

664 Caujapé-Castells, J. 2011. Jesters, red queens, boomerangs and surfers: a molecular 665 outlook on the diversity of the Canarian endemic flora. Pp: 284-324 in: Bramwell, D. \& 666 Caujapé-Castells, J. (eds.), The biology of island of floras. London: Cambridge University 667 Press.

668 Clement, M., Posada, D. \& Crandall, K. 2000. TCS: a computer program to estimate 669 gene genealogies. Molec. Ecol. 9: 1657-1660. http://dx.doi.org/10.1046/j.1365$670 \quad 294 x .2000 .01020 . x$

671 Díaz-Pérez, A., Sequeira, M., Santos-Guerra, A. \& Catalán, P. 2008. Multiple 672 colonizations, in situ speciation, and volcanism-associated stepping-stone dispersals 673 shaped the phylogeography of the macaronesian red fescues (Festuca L., Gramineae). 674 Syst. Biol. 57: 732-749. http://dx.doi.org/10.1080/10635150802302450 
675 Drummond, A.J., Suchard, M.A., Xie, D. \& Rambaut, A. 2012. Bayesian 676 phylogenetics with BEAUti and the BEAST 1.7. Mol. Biol. Evol., 29: 1969-1973. 677 http://dx.doi.org/10.1093/molbev/mss075

678 Earl, D.A. \& vonHoldt, B.M. 2012. STRUCTURE HARVESTER: a website and 679 program for visualizing STRUCTURE output and implementing the Evanno method. 680 Conservation Genet. Resour. 4: 359-361. http://dx.doi.org/10.1007/s12686-011-9548-7

681 Evanno, G., Regnaut, S. \& Goudet, J. 2005. Detecting the number of clusters of 682 individuals using the software STRUCTURE: a simulation study. Molec. Ecol. 14: 2611683 2620. http://dx.doi.org/10.1111/j.1365-294X.2005.02553.x

684 Excoffier, L., Laval, G. \& Schneider, S. 2005. Arlequin ver. 3.0: An integrated software 685 package for population genetics data analysis. Evol. Bioinform. 1: 47-50.

686 Faria, B.F., Abreu, C., Aguiar, A.F., Augusto, J., Jardim, R., Lobo, C., Oliveira, P. 687 \& Teixeira, D. 2008. La perspectiva archipelágica: Madeira. Pp: 109-128 in: Martín, 688 J.L., Arechavaleta, M., Borges, P.A.V. \& Faria, B. (eds.), Top 100. Las 100 especies 689 amenazadas prioritarias de gestión en la región europea biogeográfica de la 690 Macaronesia. Santa Cruz de Tenerife: Consejería de Medio Ambiente y Ordenación 691 Territorial, Gobierno de Canarias.

692 Felsenstein, J. 1985. Confidence limits on phylogenies: An approach using the bootstrap. 693 Evolution 39: 783-791.

694 Fernández-Palacios, J.M., de Nascimento, L., Otto, R., Delgado, J.D., García-del695 Rey, E., Ramon Arévalo, J. \& Whittaker, R.J. 2011. A reconstruction of Palaeo696 Macaronesia, with particular reference to the long-term biogeography of the Atlantic 697 island laurel forests. J. Biogeogr. 38: 226-246. http://dx.doi.org/10.1111/j.1365$698 \quad 2699.2010 .02427 . x$

699 Francisco-Ortega, J., Crawford, D.J., Santos-Guerra, A. \& Carvalho, J.A. 1996. 700 Isozyme differentiation in the endemic genus Argyranthemum (Asteraceae: 701 Anthemideae) in the Macaronesian islands. Plant Syst. Evol. 202: 137-152. 702 http://dx.doi.org/10.1007/BF00983379

703 Fuertes-Aguilar, J.M., Ray, F.J., Francisco-Ortega, F., Santos-Guerra, A. \& Jansen, 704 R.K. 2002. Molecular evidence from chloroplast and nuclear markers for multiple 705 colonizations of Lavatera (Malvaceae) in the Canary Islands. Syst. Bot. 27: 74-83. 706 http://dx.doi.org/10.1043/0363-6445-27.1.74

707 Futuyma, D.J. 2005. Evolution. Sinauer Associates, Sunderland, Massachusetts. 
708 García-Maroto, F., Manas-Fernández, A., Garrido-Cardenas, J.A., López Alonso,

709 D., Guil-Guerrero, J.L., Guzmán, B. \& Vargas, P. 2009. Delta(6)-Desaturase sequence

710 evidence for explosive Pliocene radiations within the adaptive radiation of Macaronesian

711 Echium (Boraginaceae). Molec. Phylogenet. Evol. 52: 563-574.

712 http://dx.doi.org/10.1016/j.ympev.2009.04.009

713 García-Talavera, F. 1997. Las Canarias orientales y la vecina costa africana en el 714 Holoceno. Eres 7: 55-63.

715 Geldmacher, J. \& Hoernle, K. 2000. The 72 Ma geochemical evolution of the Madeira 716 hotspot (eastern North Atlantic): recycling of Paleozoic $(\leq 500 \mathrm{Ma})$ oceanic lithosphere.

717 Earth Planet. Sc. Lett. 183: 73-92. http://dx.doi.org/10.1016/S0012-821X(00)00266-1

718 Hall, T.A. 1999. BioEdit: A user-friendly biological sequence alignment editor and 719 analysis program for Windows 95/98/NT. Nucleic Acids Symp. Ser. 41: 95-98.

720 Helfgott, D.M., Francisco-Ortega, J., Santos-Guerra, A., Jansen, R.K. \& Simpson, 721 B.B. 2000. Biogeography and breeding system evolution of the woody Bencomia alliance 722 (Rosaceae) in Macaronesia based on ITS sequence data. Syst. Bot 25: 82-97. 723 http://dx.doi.org/10.2307/2666675

724 Hubisz, M.J., Falush, D., Stephens, M. \& Pritchard, J.K. 2009. Inferring weak 725 population structure with the assistance of sample group information. Molec. Ecol. 726 Resources 9: 1322-1332. http://dx.doi.org/10.1111/j.1755-0998.2009.02591.x

727 Huson, D.H. \& Bryant, D. 2006. Application of phylogenetic networks in evolutionary 728 studies. Molec. Biol. Evol. 23: 254-267. http://dx.doi.org/10.1093/molbev/msj030

729 Jakobsson, M. \& Rosenberg, N.A. 2007. CLUMPP: a cluster matching and

730 permutation program for dealing with label switching and multimodality in analysis of

731 population structure. Bioinformatics 23: 1801-1806.

732 http://dx.doi.org10.1093/bioinformatics/btm233

733 Jardim, R., Fernandes, F. \& Carvalho, J.A. 2008. Euphorbia anachoreta Svent Pp: 734 224-225 in: Martín, J.L., Arechavaleta, M., Borges, P.A.V. \& Faria, B. (eds.), Top 100. 735 Las 100 especies amenazadas prioritarias de gestión en la región europea biogeográfica 736 de la Macaronesia. Santa Cruz de Tenerife: Consejería de Medio Ambiente y Ordenación 737 Territorial, Gobierno de Canarias.

738 Jardim, R. \& Sequeira, M.M. 2008. List of vascular plants (Pteridophyta and 739 Spermatophyta). Pp: 179-207 in: Borges, P.A.V., Abreu, C., Aguiar, A.M.F., Carvalho, 740 P., Jardim, R., Melo, I., Oliveira, P., Sérgio, C., Serrano, A.R.M. \& Vieira, P. (eds.), A 741 list of the terrestrial fungi, flora and fauna of Madeira and Selvagens 
archipelagos. Funchal and Angra do Heroísmo: Direcção Regional do Ambiente da

743 Madeira e Universidade dos Açores.

744 Lemey, P., Rambaut, A., Drummond, A.J. \& Suchard, M.A. 2009. Bayesian

745 phylogeography finds its roots. PLoS Comput. Biol., 5: e1000520.

746 http://dx.doi.org/10.1371/journal.pcbi.1000520

747 Lidén, M., Fukuhara, T., Rylander, J. \& Oxelman, B. 1997. Phylogeny and 748 classification of Fumariaceae with emphasis on Dicentra s.1., based on the plastid gene 749 rps16 intron. Plant Syst. Evol. 206: 411-420. http://dx.doi.org/10.1007/BF00987960

750 Maddison, W.P. \& Maddison, D.R. 2010. Mesquite: a modular system for evolutionary analysis. Version 2.73. http://mesquiteproject.org (accesed 21 Jul 2011). based on ITS and trnL-F sequences. Mol. Phylogenet. Evol. 44: 11051120. http://dx.doi.org/10.1016/j.ympev.2006.12.016

Mes, T.H.M. \& Hart, H.T. 1996. The evolution of growth-forms in the Macaronesian genus Aeonium (Crassulaceae) inferred from chloroplast DNA RFLPs and morphology. Molec. Ecol. 5: 351-363. http://dx.doi.org/10.1046/j.1365-294X.1996.00090.x

Mesa, R. 2009. Seguimiento de poblaciones de especies amenazadas, Euphorbia lambii Svent. La Laguna: Viceconsejería de Medio ambiente, Gobierno de Canarias. de especies amenazadas, Euphorbia bourgeauana Gay ex Boiss. in DC. La Laguna: Viceconsejería de Medio ambiente, Gobierno de Canarias.

Meudt, H.M. \& Clarke, A.C. 2007. Almost forgotten or latest practice? AFLP applications, analyses and advances. Trends Plant Sci. 12: 106-117. http://dx.doi.org/10.1016/j.tplants.2007.02.001 Karyological evolution and molecular phylogeny in Macaronesian dendroid spurges http://dx.doi.org/10.1007/s006060200014 Molero, J. \& Rovira, A.M. 1996. Fruit and seed morphology of Euphorbia sect. Balsamis. Barcelona: IV Conference on Plant Taxonomy.

773 Molero, J. \& Rovira, A.M. 1998. A note on the taxonomy of the Macaronesian

774 Euphorbia obtusifolia complex (Euphorbiaceae). Taxon 47: 321-332. 775 http://dx.doi.org/10.2307/1223761 
Molero, J. \& Rovira, A.M. 2005a. Natural hybrids in endemic Canarian dendroid spurges (Euphorbia subsect. Pachycladae). Willdenowia 35: 271-280. http://dx.doi.org/10.3372/wi.35.35207

Molero, J. \& Rovira, A.M. 2005b. Typification of some Macaronesian and Mediterranean dendroid spurges. Taxon 54: 472-474.

Moritz, C. 1994. Defining 'Evolutionarily Significant Units' for conservation. Trends Ecol. Evol. 9: 373-375. http://dx.doi.org/10.1016/0169-5347(94)90057-4

Müller, K. 2005. SeqState - primer design and sequence statics for phylogenetic DNA data sets. Appl. Bioinf. 4: 65-69. http://dx.doi.org/10.2165/00822942-200504010-00008 Nei, M. \& Li, W.H. 1979. Mathematical-model for studying genetic-variation in terms of restriction endonucleases. Proc. Natl. Acad. Sci. U.S.A. 76: 5269-5273. Nogales, M. 1985. Contribución al estudio de la flora y fauna en los montes de Pajonales, Ojeda e Inagua (Gran Canaria). Dissertation, Universidad de La Laguna, Canary Islands, Spain.

790 Nylander, J.A.A. 2004. MrModeltest, version 2. Program distributed by the author. Uppsala: Evolutionary Biology Centre, Uppsala University.

Park, S.J., Korompai, E.J., Francisco-Ortega, J., Santos-Guerra, A. \& Jansen, R.K. 2001. Phylogenetic relationships of Tolpis (Asteraceae: Lactuceae) based on $n d h F$ sequence data. Pl. Syst. Evol. 226: 23-33. http://dx.doi.org/10.1007/s006060170071 J.M., Shaw, J.A. \& Vanderpoorten, A. 2015. Approximate Bayesian Computation reveals the crucial role of oceanic islands for the assembly of continental biodiversity. Syst. Biol. 64: 579-589. http://dx.doi.org/10.1093/sysbio/syv013

Pedro, J.G. 1942. Estudo geobotânico da Serra da Arrábida. I. Reconhecimento geral.

800 Agron. Lusit. 4: 101-136.

801 Press, J.R. \& Short, M.J. 1994. Flora of Madeira. London: HMSO.

802 Pritchard, J.K., Stephens, M. \& Donnelly, P. 2000. Inference of population structure 803 using multilocus genotype data. Genetics 155: 945-959.

804 Rambaut, A., Suchard, M.A., Xie, D. \& Drummond, A.J. 2013. Tracer v1.6, 805 http://beast.bio.ed.ac.uk/software/tracer/

806 Reyes-Betancort, J.A., Santos Guerra, A., Rosana Guma, I., Humphries, C.J. \& 807 Carine, M.A. 2008. Diversity, rarity and the evolution and conservation of the Canary 808 Islands endemic flora. Anales Jard. Bot. Madrid 65: 25-45. 
809 Riina, R., Peirson, J.A., Geltman, D.V., Molero, J., Frajman, B., Pahlevani, A., 810 Barres, L., Morawetz, J.J., Salmaki, Y., Zarre, S., Kryukov, A., Bruyns, P.V. \& 811 Berry, P.E. 2013. A worldwide molecular phylogeny and classification of the leafy 812 spurges, Euphorbia subgenus Esula (Euphorbiaceae). Taxon 62: 316-342. 813 http://dx.doi.org/10.12705/622.3

814 Rohlf, F.J. 1997. NTSYS-Pc. Numerical taxonomy and multivariate analysis system, v. 815 1.80. New York: Exeter Software.

816 Romeiras, M.M., Monteiro, F., Duarte, M.C., Schaefer, H. \& Carine, M. 2015. 817 Patterns of genetic diversity in three plant lineages endemic to the Cape Verde Islands. 818 AoB PLANTS 7: plv051. http://dx.doi:10.1093/aobpla/plv051

819 Ronquist, F. \& Huelsenbeck, J.P. 2003. MrBAYES 3: Bayesian phylogenetic inference 820 under mixed models. Bioinformatics 19: 1572-1574. 821 http://dx.doi.org/10.1093/bioinformatics/btg180

822 Rosenberg, N.A. 2004. DISTRUCT: a program for the graphical display of population 823 structure. Molec. Ecol. Notes 4: 137-138. http://dx.doi.org/10.1590/S1415$824 \quad 47572013000100017$

825 Sanmartín, I., Van der Mark, P. \& Ronquist, F. 2008. Inferring dispersal: a Bayesian 826 approach to phylogeny-based island biogeography, with special reference to the Canary 827 Islands. J. Biogeogr. 35: 428-449. http://dx.doi.org/10.1111/j.1365-2699.2008.01885.x

828 Santos-Guerra, A. 1999. Origen y evolución de la flora de Canarias. Pp: 107-129 in 829 Fernández-Palacios, J.M., Bacallado, J.J. \& Belmonte, J.A. (eds.), Ecología y cultura en 830 Canarias. Santa Cruz de Tenerife: Organismo Autónomo de Museos y Centros - Cabildo 831 de Tenerife.

832 Silvertown, J, Francisco-Ortega, J. \& Carine, M. 2005. The monophyly of island 833 radiations: an evaluation of niche pre-emption and some alternative explanations. J. Ecol. 834 93: 653-657. doi:10.1111/j.1365-2745.2005.01038.x

835 Simmons, M.P. \& Ochoterena, H. 2000. Gaps as characters in sequence-based 836 phylogenetic analyses. $\quad$ Syst. $\quad$ Biol. 49 369-381. 837 http://dx.doi.org/10.1016/j.ympev.2006.07.021

838 Sunding, P. 1979. Origins of the Macaronesian flora. Pp:. 13-40 in: Bramwell, D. (ed.), 839 Plants and islands. London: Academic Press.

840 Sventenius, E.S. 1960. Additamentum ad floram canariensem. Madrid: Agronomiarum 841 Investigationem Nationale Hispanicum Institutum. 
842 Swofford, D.L. 2002. PAUP*: Phylogenetic analysis using parsimony (*and other 843 methods), version 4.0b 10. Sunderland, Massachusetts: Sinauer.

844 Van de Peer, Y. \& De Wachter, Y. 1994. TREECON for Windows: a software package 845 for the construction and drawing of evolutionary trees for the Microsoft Windows 846 environment. Comput. Applic. Biosci. 10 : 569-570.

847 http://dx.doi.org/10.1093/bioinformatics/10.5.569

848 Vos, P., Hogers, R., Bleeker, M., Reijans, M., Vandelee, T., Hornes, M., Frijters, A., 849 Pot, J., Peleman, J., Kuiper, M. \& Zabeau, M. 1995. AFLP: a new technique for DNA 850 fingerprinting. Nucl. Acids Res. 23: 4407-4414. http://dx.doi.org/10.1093/nar/23.21.4407

851 Whittaker, R.J. \& Fernández-Palacios, J.M. 2007. Island biogeography: ecology, 852 evolution, and conservation. Oxford: Oxford University Press. 
Fig. 1. Sampling localities of 53 populations of the 11 Euphorbia species included in the study. Details on localities and number of specimens sampled are given in Table 2.

Fig. 2. Neighbour-net diagram of the whole AFLPs dataset constructed with Splitstree v4.11.3. BS values above $80 \%$ from a NJ analysis of the same dataset are shown only on main clades. Species names are labelled as: ANA, E. anachoreta; APH, E. aphylla; BER, E. berthelotii; BOU, E. bourgaeana; LAMB, E. lamarckii var. broussonetti; LAML, E. lamarckii var. lamarckii; PED, E. pedroi; PIS, E. piscatoria; REG, E. regis-jubae; TUC, E. tuckeyana. The population codes as shown in Fig. 1.

Fig. 3. Neighbour Joining tree of 189 individuals from 53 populations used in the AFLPs analyses. Numbers above branches indicate BS support values $>50 \%$. Species names are labelled as: ANA, E. anachoreta; APH, E. aphylla; BER, E. berthelotii; BOU, E. bourgaeana; LAM, E. lamarckii; PED, E. pedroi; PIS, E. piscatoria; REG, E. regisjubae; TUC, E. tuckeyana. Population numbers follow Fig. 1.

Fig. 4. Bar plots from the genetic structure analyses obtained with Structure v2.3.3. In all panels, vertical bars estimate the proportion of each individual's genome that comes from the $K$ postulated genetic groups. An admixture model was used for all analyses presented. (A) $K=7$ for the whole dataset excluding E. tuckeyana. (B) $K=3$ for 28 E. bourgaeana individuals. (C) $K=4$ for 45 E. lamarckii individuals. (D) $K=2$ for 30 E. piscatoria individuals. (E) $K=4$ for 35 E. tuckeyana individuals. (F) $K=2$ for 37 individuals of E. regis-jubae and E. pedroi. Species names and populations numbers are labelled as in Fig. 1. Geographic origin is labelled as: ET, east Tenerife; F, Fuerteventura; G, La Gomera; GC, Gran Canaria; H, El Hierro; L, Lanzarote; M, Madeira; Mo, Morocco; P, La Palma; PS, Porto Santo; S, Santiago; SA, Santo Antão; SV, São Vicente; T, Tenerife; WT, west Tenerife.

878 Fig. 5. Spatial diffusion of subsect. Macaronesicae populations based on the MCC tree analysed with BEAST in an RRW model at four times intervals. The red lines represent the branches of the MCC tree. The blue regions represent the 80\%-HPD uncertainty in the location of ancestral branches with a gradient between light and dark representing older vs. younger diffusion events.

Fig. 6. Distribution and relationships of cpDNA haplotypes. (A): Geographic distribution of the 13 haplotypes detected. Donut chart slices indicate proportions of haplotypes in each population sampled. (B): Statistical parsimony network of cpDNA haplotypes. Circles are proportional to the number of individuals containing each 
887 haplotype, black circles indicate unsampled intermediate haplotypes. Discontinuous lines 888 represent uncertainty about the order of character changes and are shown to indicate 889 alternative relationships in the diagram. Species names and populations numbers are 890 labelled as in Fig. 1.

891 Fig. 7. Ancestral character state reconstruction for each morphological character 892 studied based on the maximum likelihood NJ tree inferred from Nei and Li distances from 893 the AFLP data reconstructed with Mesquite v2.74.

894 Fig. S1. Principal Coordinate Analysis of 346 AFLP markers for the whole dataset 895 excluding E. tuckeyana based on Dice's similarity coefficient.

896 Fig. S2. Phylogenetic relationships among plastid DNA haplotypes of subsect. 897 Macaronesicae, six species of subsect. Africanae and one species of sect. Pachycladae 898 based on Bayesian inference. Bayesian posterior probabilities $(\geq 0.50)$ and bootstrap 899 values $(\geq 50 \%)$ are indicated above branches. 


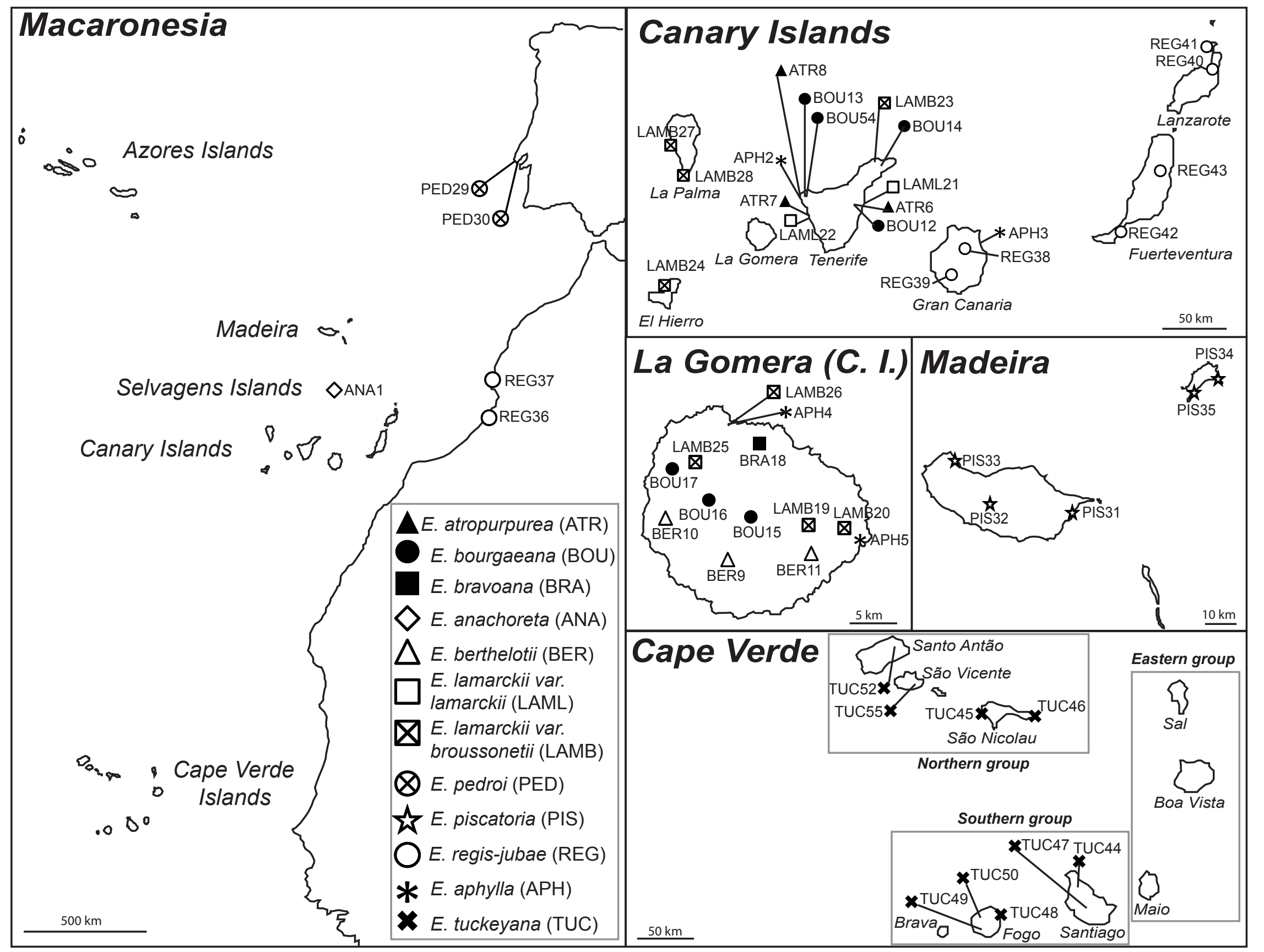




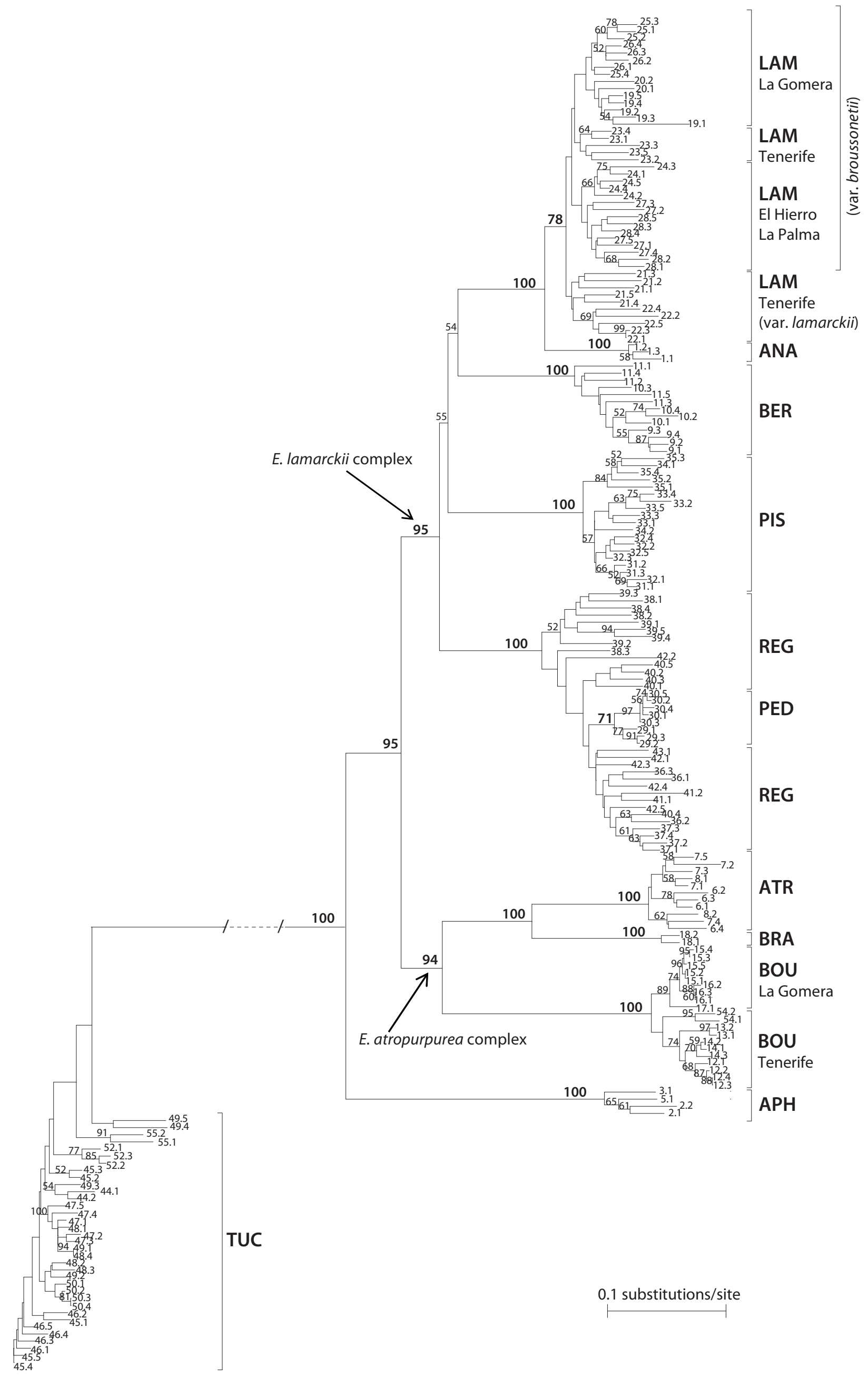




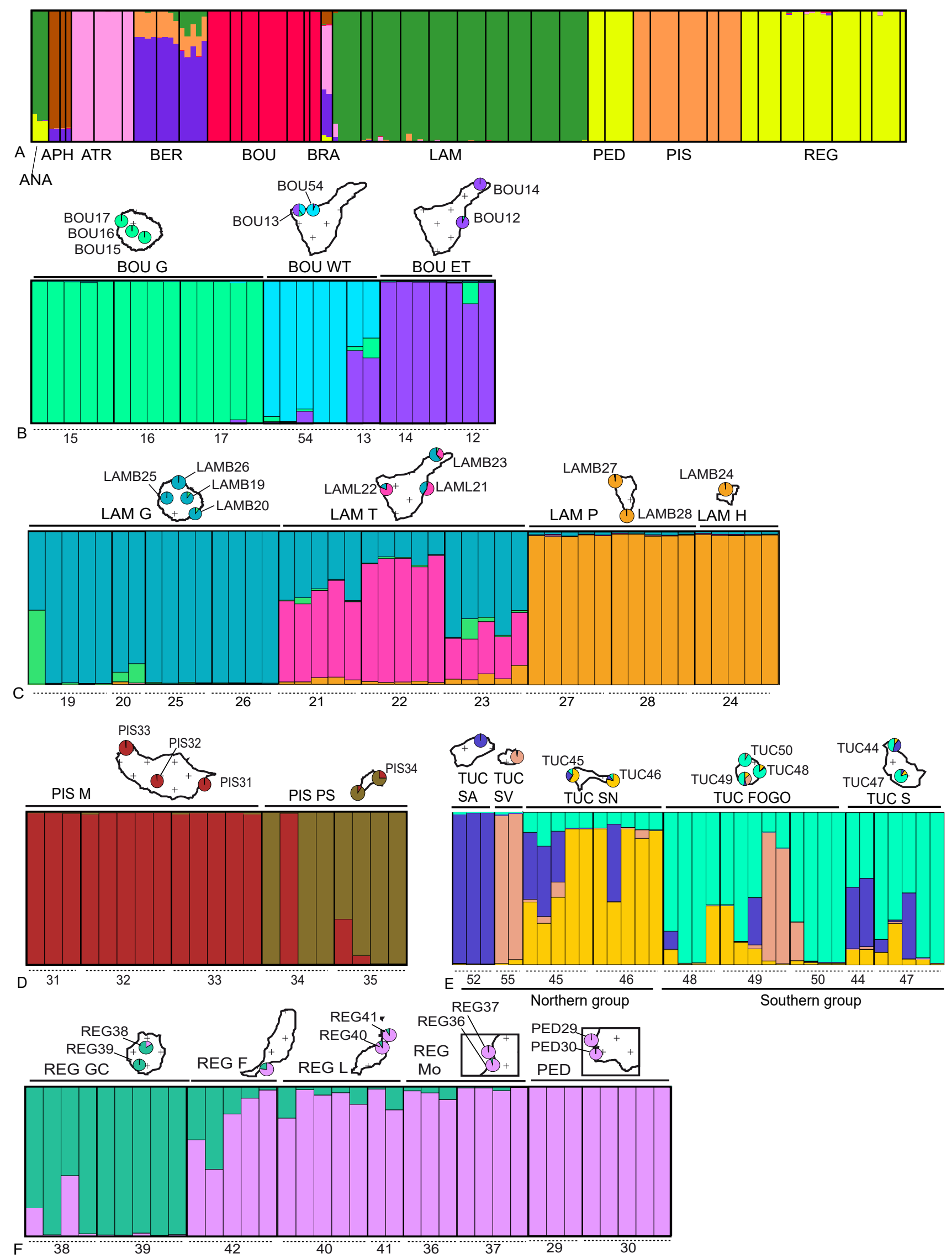



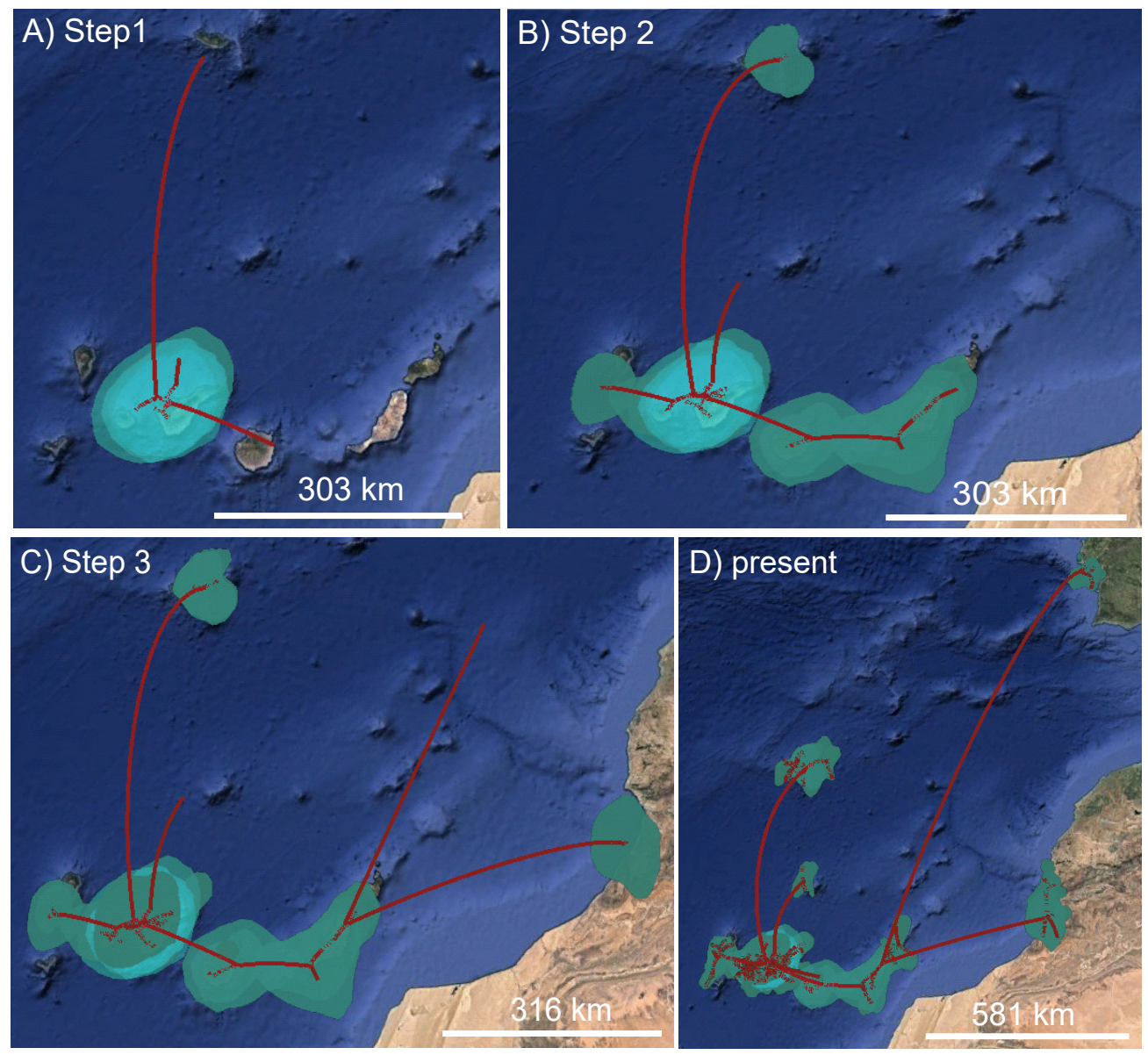


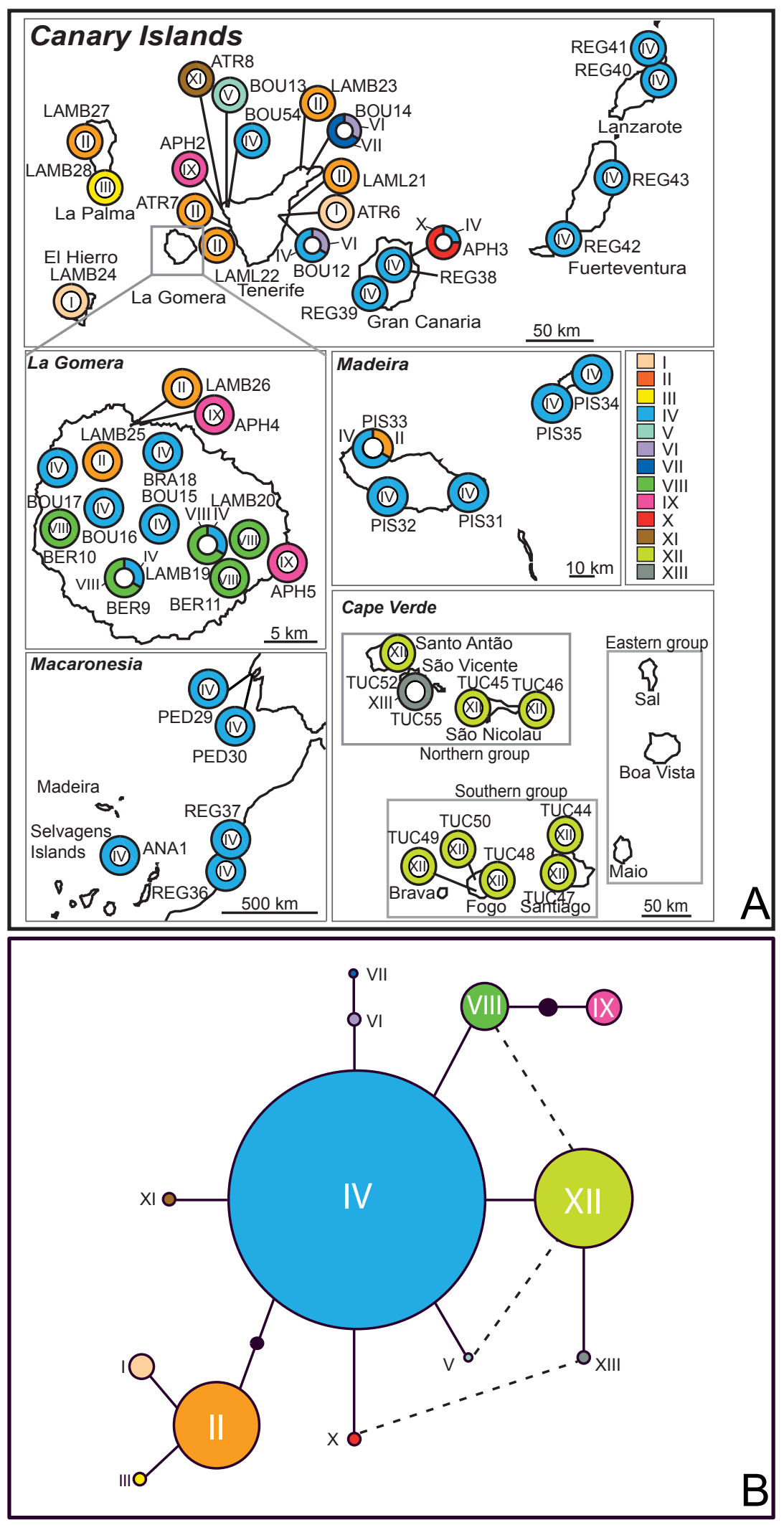



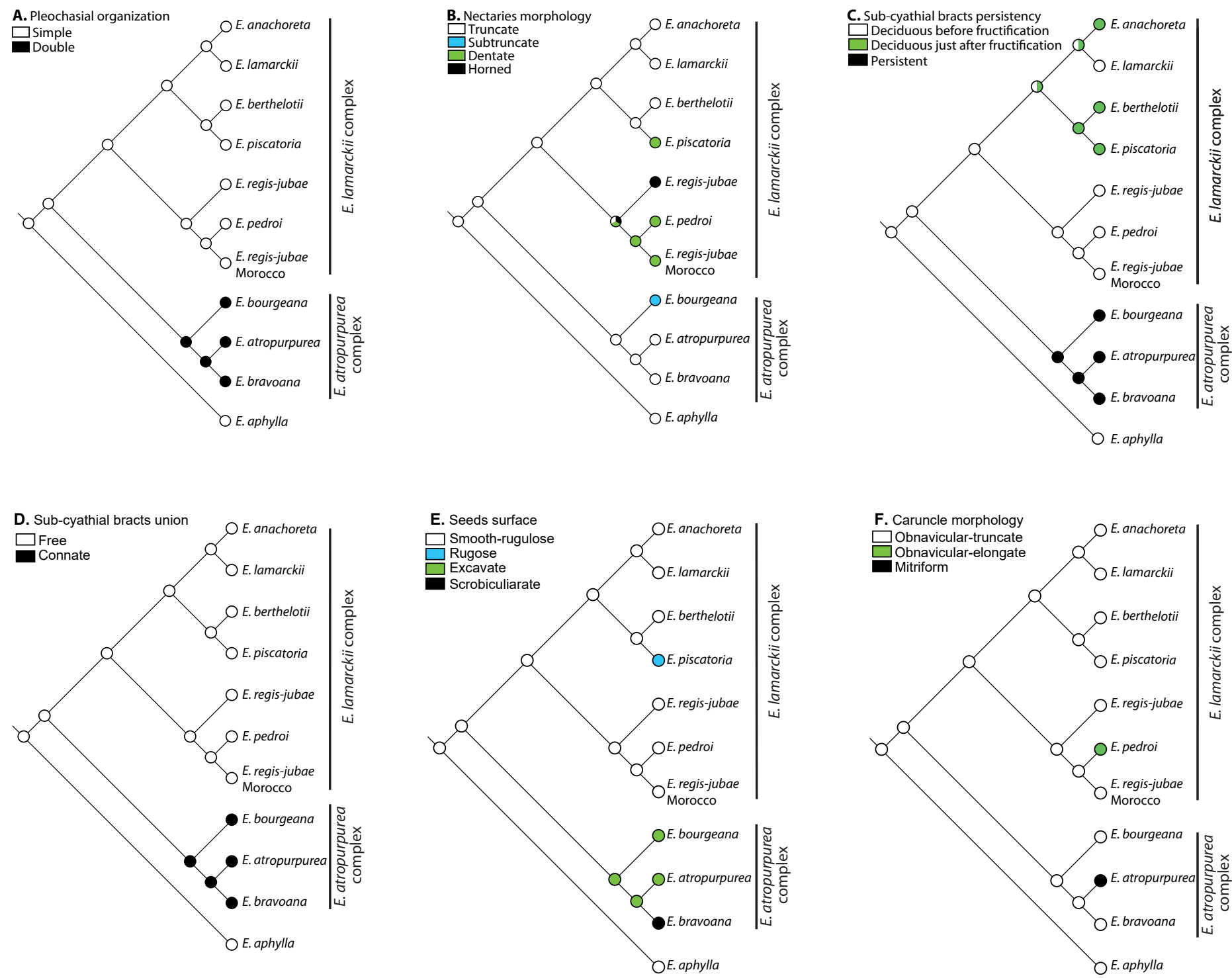

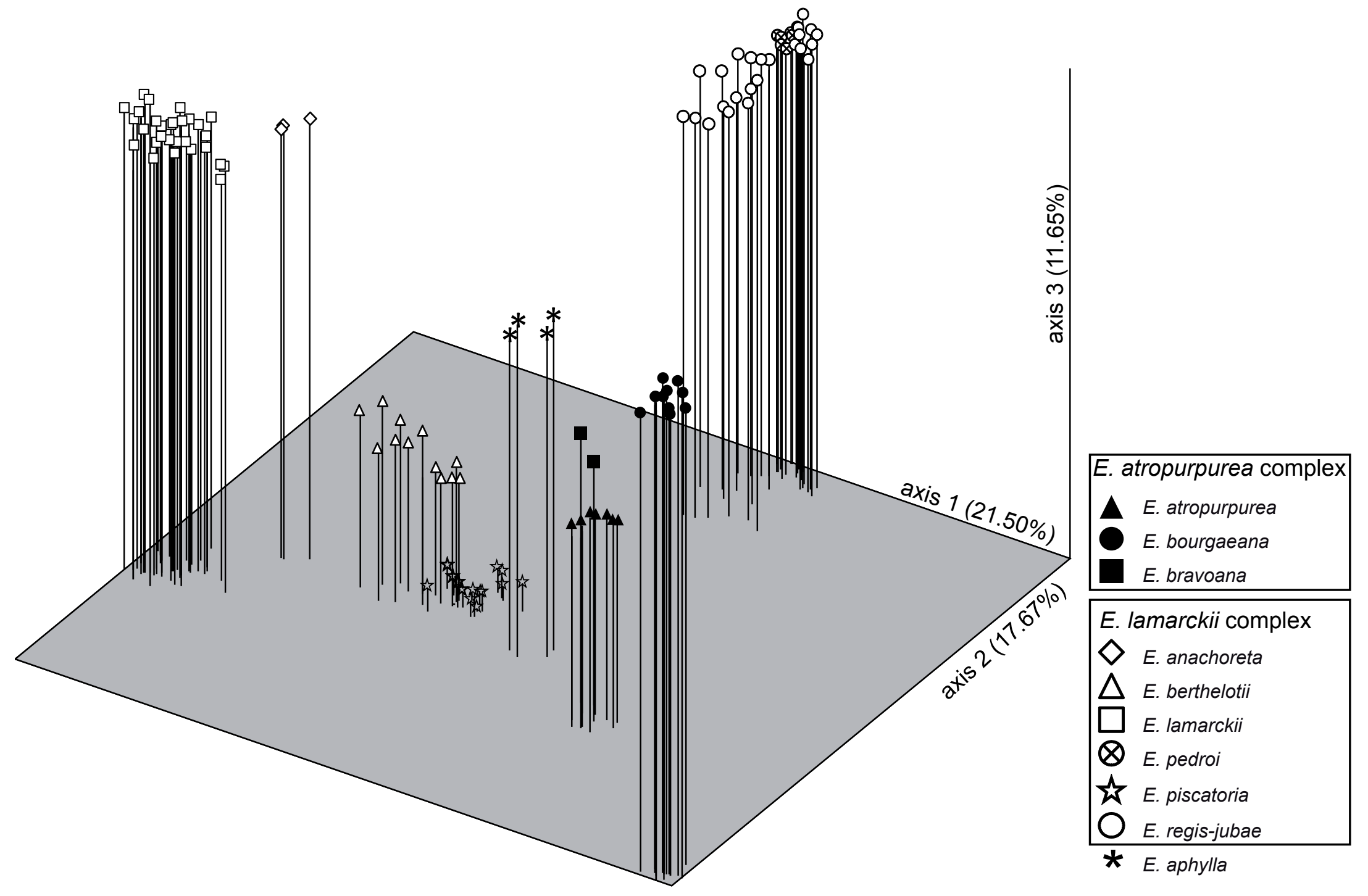


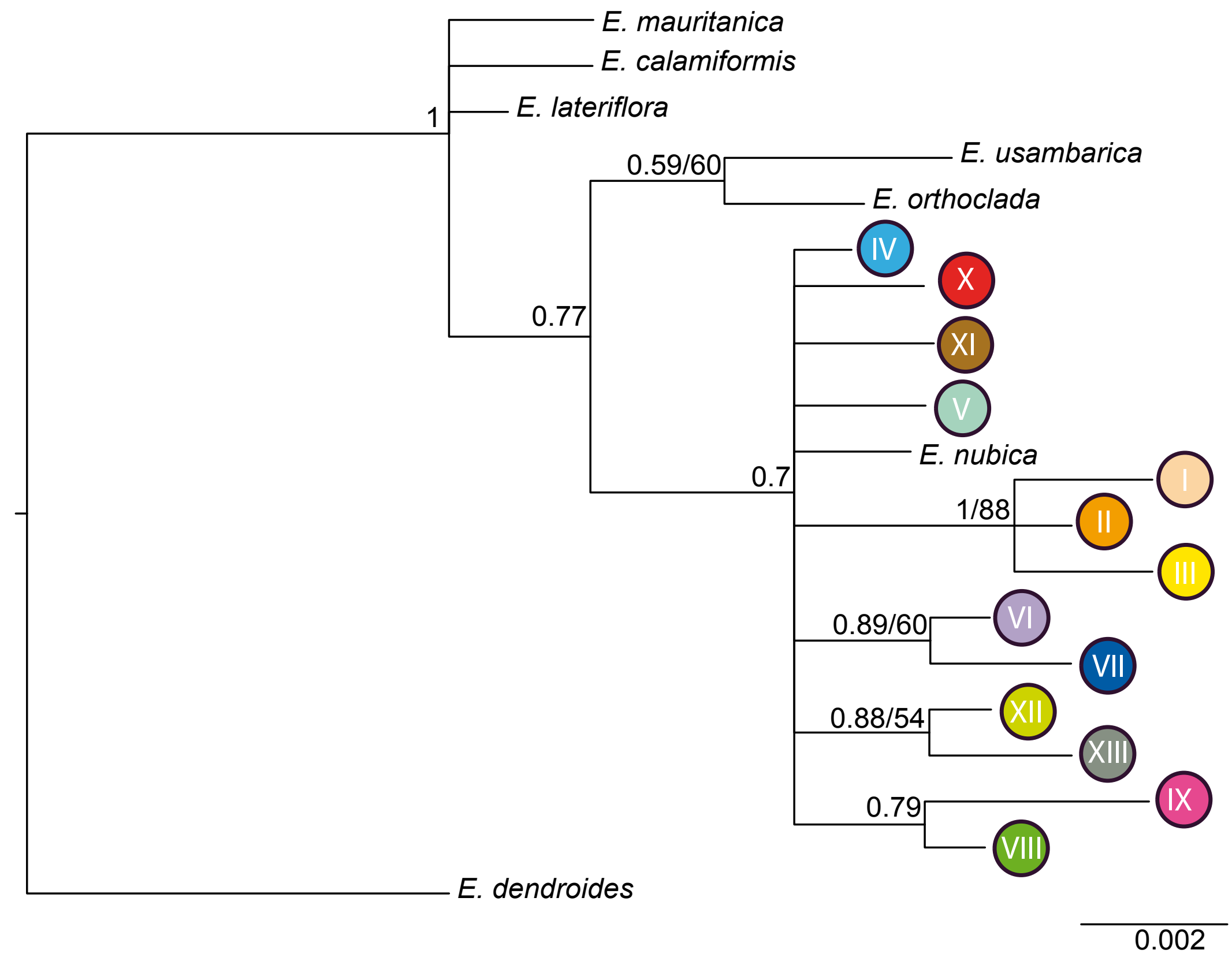


Table 1. Diagnostic morphological and ecological characters of the taxonomic complexes of Euphorbia sect. Aphyllis in Macaronesia (Molero \& al., 2002).

\begin{tabular}{|c|c|c|c|c|c|}
\hline & Leaves & Synflorescence & $\begin{array}{l}\text { Sub-cyathial } \\
\text { bracts }\end{array}$ & Seeds & Ecology \\
\hline $\begin{array}{l}\text { E. atropurpurea } \\
\text { complex including } E \text {. } \\
\text { atropurpurea, } E \text {. } \\
\text { bourgaeana and } E \text {. } \\
\text { bravoana }\end{array}$ & $\begin{array}{l}\text { Semi- } \\
\text { persistent }\end{array}$ & Double & $\begin{array}{l}\text { Large }(10-20 \mathrm{~mm}) \\
\text { Connate } \\
\text { Persistent }\end{array}$ & $\begin{array}{l}\text { Excavate to } \\
\text { scrobiculariate }\end{array}$ & $\begin{array}{l}\text { Mesophilous and meso-hygrophilous } \\
\text { habitats }\end{array}$ \\
\hline $\begin{array}{l}\text { E. lamarckii complex } \\
\text { including } \text { E. } \\
\text { anachoreta, E. } \\
\text { berthelotii, E. lamarckii } \\
\text { var. lamarckii, E. } \\
\text { lamarckii var. } \\
\text { broussonetti, E. pedroi, } \\
\text { E. piscatoria, E. regis- } \\
\text { jubae and E. tuckeyana }\end{array}$ & Deciduous & $\begin{array}{l}\text { Simple } \\
\text { lax }\end{array}$ & $\begin{array}{l}\text { Small }(<10 \mathrm{~mm}) \\
\text { Free to the base } \\
\text { Deciduous }\end{array}$ & Smooth to rugose & Xerophilous and mesophilous habitats \\
\hline E. aphylla & Absent & $\begin{array}{l}\text { Simple } \\
\text { congested }\end{array}$ & $\begin{array}{l}\text { Small }(<2 \mathrm{~mm}) \\
\text { Free } \\
\text { Deciduous }\end{array}$ & Smooth to rugulose & Xerophilous-halophilous habitats \\
\hline
\end{tabular}


Table 2. Taxa sampled, general distribution, population codes as shown in Fig. 1, localities, voucher number and number of individuals used for the study of AFLPs and plastid DNA haplotypes. N AFLP is the number of individuals used in the AFLP study, in parentheses is the number of individuals used in some Structure analyses including only three primer pairs. In the haplotypes column the number of individuals for each haplotype is indicated in parentheses.

\begin{tabular}{|c|c|c|c|c|c|}
\hline Species & Distribution & Pop. & Locality, Collection and Voucher Number & N AFLP & Haplotypes \\
\hline $\begin{array}{l}\text { Euphorbia anachoreta } \\
\text { Svent. }\end{array}$ & Selvagens Islands & ANA1 & Portugal, Madeira, Ilhas Selvagens, National Park s.n. (BC) & 3 & IV (4) \\
\hline \multirow{4}{*}{$\begin{array}{l}\text { Euphorbia aphylla } \\
\text { Brouss. ex Willd }\end{array}$} & \multirow{4}{*}{$\begin{array}{l}\text { Gran Canaria, La Gomera } \\
\text { and Tenerife } \\
\text { (Canary Islands) }\end{array}$} & APH2 & $\begin{array}{c}\text { Spain, Canary Islands, Tenerife, Teno, Punta del Fraile, Barres } 74 \text { \& } \\
\text { Vilatersana (BC 873330) }\end{array}$ & $2(4)$ & IX (3) \\
\hline & & APH3 & $\begin{array}{l}\text { Spain, Canary Islands, Gran Canaria, La Isleta, close to the military } \\
\text { installations, road Las Coloradas, López-Pujol } 9 \text { \& Caujapé-Castells } \\
\text { (BC 944367) }\end{array}$ & $1(2)$ & $\mathrm{X}(3), \mathrm{IV}(1)$ \\
\hline & & APH4 & $\begin{array}{c}\text { Spain, Canary Islands, La Gomera, Vallehermoso, playa de Vallehermoso, } \\
\text { Barres } 97 \text { \& Vilatersana (BC 873340) }\end{array}$ & $-(2)$ & IX (3) \\
\hline & & APH5 & $\begin{array}{c}\text { Spain, Canary Islands, La Gomera, San Sebastián de la Gomera, Puntallana } \\
\text { Natural Reserve, Nuestra Señora de Guadalupe Chapel, Barres } 109 \text { \& } \\
\text { Vilatersana (BC 873348) }\end{array}$ & $1(3)$ & IX (3) \\
\hline \multirow{3}{*}{$\begin{array}{l}\text { Euphorbia atropurpurea } \\
\text { Brouss. }\end{array}$} & \multirow{3}{*}{$\begin{array}{l}\text { Tenerife } \\
\text { (Canary Islands) }\end{array}$} & ATR6 & $\begin{array}{c}\text { Spain, Canary Islands, Tenerife, Güímar, old Güímar road (Güímar } \\
\text { Viewpoint), Barres } 63 \text { et al. (BC 873324) }\end{array}$ & 4 & I (3) \\
\hline & & ATR7 & $\begin{array}{l}\text { Spain, Canary Islands, Tenerife, Guía de Isora, Barres } 66 \text { \& Vilatersana } \\
\text { (BC 873325) }\end{array}$ & 5 & II (3) \\
\hline & & ATR8 & $\begin{array}{l}\text { Spain, Canary Islands, Tenerife, Teno, Punta del Fraile, Barres } 75 \text { et al. } \\
\text { (BC 873331) }\end{array}$ & 2 & $\mathrm{XI}(3)$ \\
\hline \multirow{3}{*}{$\begin{array}{l}\text { Euphorbia berthelotii } \\
\text { Bolle ex Boiss. }\end{array}$} & \multirow{3}{*}{$\begin{array}{l}\text { La Gomera (Canary } \\
\text { Islands) }\end{array}$} & BER9 & $\begin{array}{c}\text { Spain, Canary Islands, La Gomera, road from El Pajarito to Alajeró, Barres } 99 \\
\text { \& Vilatersana (BC 873342) }\end{array}$ & 4 & $\begin{array}{l}\text { IV (1), } \\
\text { VIII (2) }\end{array}$ \\
\hline & & BER10 & $\begin{array}{c}\text { Spain, Canary Islands, La Gomera, Gran Rey Valley, near Cesar Manrique } \\
\text { House, Barres } 112 \text { \& Vilatersana (BC 873349) }\end{array}$ & 4 & VIII (3) \\
\hline & & BER11 & $\begin{array}{l}\text { Spain, Canary Islands, La Gomera, Santiago, between Sabinares turning and } \\
\text { Santiago beach, Barres } 116 \& \text { Vilatersana (BC 873351) }\end{array}$ & 5 & VIII (3) \\
\hline
\end{tabular}




\begin{tabular}{|c|c|c|c|c|c|}
\hline \multirow{7}{*}{$\begin{array}{l}\text { Euphorbia bourgaeana } \\
\text { J.Gay ex Boiss. }\end{array}$} & & BOU12 & $\begin{array}{l}\text { Spain, Canary Islands, Tenerife, Güímar, Chamoco ravine, Barres } 61 \text { et al. } \\
\text { (BC 873323) }\end{array}$ & $4(4)$ & $\begin{array}{l}\text { IV }(1) \\
\text { VI }(2)\end{array}$ \\
\hline & & BOU13 & $\begin{array}{l}\text { Spain, Canary Islands, Tenerife, Punta de Teno, El Charco ravine, Barres } 73 \text { et } \\
\text { al. (BC 873329) }\end{array}$ & $2(2)$ & V (2) \\
\hline & \multirow{5}{*}{$\begin{array}{l}\text { La Gomera and Tenerife } \\
\text { (Canary Islands) }\end{array}$} & BOU14 & $\begin{array}{l}\text { Spain, Canary Islands, Tenerife, Anaga, Roque Negro, Barres } 78 \text { et al. } \\
\text { (BC 873381) }\end{array}$ & $3(3)$ & $\begin{array}{l}\text { VI (1), } \\
\text { VII (2) }\end{array}$ \\
\hline & & BOU15 & $\begin{array}{c}\text { Spain, Canary Islands, La Gomera, Garajonay National Park, Los Noruegos, } \\
\text { Barres } 94 \text { et al. (BC 873337) }\end{array}$ & $5(5)$ & IV (3) \\
\hline & & BOU16 & $\begin{array}{l}\text { Spain, Canary Islands, La Gomera, road from El Cercado to Las Hayas, Barres } \\
\qquad 101 \text { et al. (BC 873344) }\end{array}$ & $3(4)$ & IV (3) \\
\hline & & BOU17 & $\begin{array}{c}\text { Spain, Canary Islands, La Gomera, Garajonay National Park, Chorros de } \\
\text { Epina, Barres } 103 \text { et al. (BC 873346) }\end{array}$ & $1(5)$ & IV (3) \\
\hline & & BOU54 & $\begin{array}{c}\text { Spain, Canary Islands, Tenerife, Teno, Chajabe-Los Martínez, Mesa et al. s.n. } \\
\text { (Personal Herbarium) }\end{array}$ & $3(5)$ & IV (3) \\
\hline $\begin{array}{l}\text { Euphorbia bravoana } \\
\text { Svent. }\end{array}$ & $\begin{array}{c}\text { Tenerife } \\
\text { (Canary Islands) } \\
\end{array}$ & BRA18 & $\begin{array}{l}\text { Spain, Canary Islands, La Gomera, road from Agulo to Las Rosas, Barres } 96 \text { \& } \\
\text { Vilatersana. (BC 873339) }\end{array}$ & 2 & IV (3) \\
\hline \multirow{2}{*}{$\begin{array}{l}\text { Euphorbia lamarckii } \\
\text { Sweet var. lamarckii }\end{array}$} & \multirow{2}{*}{$\begin{array}{l}\text { South Tenerife (Canary } \\
\text { Islands) }\end{array}$} & LAM21 & $\begin{array}{l}\text { Spain, Canary Islands, Tenerife, Güímar, Barres } 54 \text { \& Vilatersana } \\
\text { (BC 873322) }\end{array}$ & 5 & II (3) \\
\hline & & LAM22 & $\begin{array}{l}\text { Spain, Canary Islands, Tenerife, Guía de Isora, Barres } 67 \& \text { Vilatersana } \\
\text { (BC 873326) }\end{array}$ & 5 & II (3) \\
\hline \multirow{6}{*}{$\begin{array}{c}\text { Euphorbia lamarckii var. } \\
\text { broussonetii (Willd. ex } \\
\text { Link) Molero \& Rovira }\end{array}$} & \multirow{6}{*}{$\begin{array}{c}\text { North Tenerife, La } \\
\text { Gomera, La Palma and El } \\
\text { Hierro } \\
\text { (Canary Islands) }\end{array}$} & LAM19 & $\begin{array}{l}\text { Spain, Canary Islands, La Gomera, road from Hermigua to Las Casetas, Altos } \\
\text { de Uteza, Barres } 110 \text { \& Vilatersana (BC 873390) }\end{array}$ & 5 & $\begin{array}{l}\text { IV (1), } \\
\text { VIII (2) }\end{array}$ \\
\hline & & LAM20 & $\begin{array}{l}\text { Spain, Canary Islands, La Gomera, San Sebastián de la Gomera, Puntallana } \\
\text { Natural Reserve, Riscos de Aluce, Barres } 115 \text { \& Vilatersana (BC 873391) }\end{array}$ & 2 & VIII (2) \\
\hline & & LAM23 & $\begin{array}{l}\text { Spain, Canary Islands, Tenerife, Anaga, Punta de Hidalgo, Barres } 85 \& \\
\text { Vilatersana (BC 873387) }\end{array}$ & 5 & II (3) \\
\hline & & LAM24 & $\begin{array}{c}\text { Spain, Canary Islands, El Hierro, Frontera, Punta de la Dehesa, El Verodal } \\
\text { beach, Barres } 86 \text { \& Vilatersana (BC } 873333)\end{array}$ & 5 & I (3) \\
\hline & & LAM25 & $\begin{array}{l}\text { Spain, Canary Islands, La Gomera, between Epina and Vallehermoso, near } \\
\text { Macayo, Barres } 113 \text { \& Vilatersana (BC 873350) }\end{array}$ & 4 & II (3) \\
\hline & & LAM26 & $\begin{array}{l}\text { Spain, Canary Islands, La Gomera, Vallehermoso, Barres } 98 \text { \& Vilatersana } \\
\text { (BC 873341) }\end{array}$ & 4 & II (3) \\
\hline
\end{tabular}


Spain, Canary Islands, La Palma, Las Angustias ravine, Los Llanos, Barres

$$
119 \text { et al. (BC 873353) }
$$

LAM28 Spain, Canary Islands, La Palma, Fuencaliente, Barres 124 et al. (BC 873357)

Portugal, Sesimbra, Cabo Espichel, Chao dos Navegantes, J. Molero

III (3)

\begin{tabular}{lc}
\hline Euphorbia pedroi & Sesimbra Peninsula \\
Molero \& Rovira & (Portugal)
\end{tabular}

PED29 31/03/2010 (BCN 70795)

PED30

Portugal, Sesimbra, Serra de Ares, between California beach and Cape Ares, $J$. Molero 30/03/2010 (BCN 70791)

IV (3)

\begin{tabular}{c}
\hline Euphorbia piscatoria Ait. \\
$\begin{array}{c}\text { Madeira, Porto Santo \& } \\
\text { Desertas Islands }\end{array}$ \\
\hline $\begin{array}{c}\text { Euphorbia regis-jubae } \quad \text { Fuerteventura, Lanzarote, } \\
\text { Gran Canaria and west } \\
\text { coast of Morocco }\end{array}$
\end{tabular}

PIS31

Portugal, Madeira, Machico, Machico viewpoint, Barres 126 et al. (BC 873359)

IV (3)

PIS32 Portugal, Madeira, Serra de Água, Pousada dos Vinhaticos, Barres 130 et al. (BC 873394)

$3(3)$

IV (3)

PIS33

Portugal, Madeira, Ribeira da Janela, Barres 131 et al. (BC 873395)

$5(5)$

5 (5) II (1), IV (2)

PIS34

Portugal, Madeira, Porto Santo, Roche de Nosa Senhora, Barres 159 et al. (BC

Portugal, Madeira, Porto Santo, Pico Ana Ferreira south slope, Barres 161 et al. (BC 873374)

$2(4) \quad$ IV (3)

PIS35

REG36

Morocco, road from Tiznit to Souk el Arba du Sahel, near Mirleft, Barres 50 \&

$$
\text { López-Viñallonga (BC 873320) }
$$

$4(4)$

REG37

REG38

Morocco, between Agadir and Essouira, Cape Ghir, Barres 51 \& LópezViñallonga (BC 873321)

Spain, Canary Islands, Gran Canaria, between Vega de San Mateo and Teror, López-Pujol 1 \& Caujapé-Castells (BC 942715)

REG39

Spain, Canary Islands, Gran Canaria, El Sao, Agaete Valley, López-Pujol 2 \&

$$
\text { Caujapé-Castells (BC 942850) }
$$

REG40

Spain, Canary Islands, Lanzarote, Lomo de En medio, Los Valles, López-Pujol

$$
4 \text { \& Olangua (BC 943147) }
$$

$4 \quad$ IV $(3)$

REG41 Spain, Canary Islands, Lanzarote, Graciosa Island, between Agujas and Morro de las Pedreras, López-Pujol 6 \& Olangua (BC 943764) 


\begin{tabular}{|c|c|c|c|c|c|}
\hline \multirow{9}{*}{$\begin{array}{l}\text { Euphorbia tuckeyana } \\
\text { Steud. }\end{array}$} & \multirow{9}{*}{$\begin{array}{c}\text { Boa Vista, Brava, Fogo, } \\
\text { Sal, Santiago, Santo } \\
\text { Antao, Sao Nicolau, Sao } \\
\text { Vicente (Cape Verde) }\end{array}$} & TUC44 & $\begin{array}{l}\text { Cape Verde, Santiago, Sierra Malagueta, Galbany-Casals } 2100 \& \text { Molero } \\
\text { (BCN 67400) }\end{array}$ & 2 & XII (3) \\
\hline & & TUC45 & $\begin{array}{c}\text { Cape Verde, São Nicolau, between Barril and Praia Branca, Covadinha ravine, } \\
\text { Galbany-Casals } 2104 \text { \& Molero (BCN 67404) }\end{array}$ & 5 & XII (3) \\
\hline & & TUC46 & $\begin{array}{l}\text { Cape Verde, São Nicolau, Alto das Cabaças, Galbany-Casals } 2107 \text { \& Molero } \\
\text { (BCN 67407) }\end{array}$ & 5 & XII (3) \\
\hline & & TUC47 & $\begin{array}{c}\text { Cape Verde, Santiago, Pico de Antonia mountains, Galbany-Casals } 2121 \& \\
\text { Molero (BCN 67421) }\end{array}$ & 5 & XII (3) \\
\hline & & TUC48 & $\begin{array}{c}\text { Cape Verde, Fogo, between Achada Grande and Corvo, Galbany-Casals } 2125 \\
\text { \& Molero (BCN 67425) }\end{array}$ & 4 & XII (3) \\
\hline & & TUC49 & $\begin{array}{l}\text { Cape Verde, Fogo, Cha das Caldeiras, Galbany-Casals } 2128 \text { \& Molero } \\
\text { (BCN 67428) }\end{array}$ & 5 & XII (3) \\
\hline & & TUC50 & $\begin{array}{l}\text { Cape Verde, Fogo, Ribeira Felipe after Lomba, Galbany-Casals } 2133 \& \\
\text { Molero (BCN 67433) }\end{array}$ & 4 & XII (3) \\
\hline & & TUC52 & $\begin{array}{l}\text { Cape Verde, Santo Antâo, Cova, Agua das Caldeiras, Molero s } n \text {. \& Rovira } \\
\text { (BCN 58767) }\end{array}$ & 3 & XII (3) \\
\hline & & TUC55 & Cape Verde, São Vicente, Monte Verde, Molero s $n$. \& Rovira (BCN 58754) & 2 & XIII (3) \\
\hline
\end{tabular}


Table 3. Optimal number of K obtained with Structure v2.3.3. $\Delta \mathrm{K}$ values are given for each $K$ considered. Numbers in bold indicate the values for K chosen as best in the different analyses. Species name codes as in Fig. 1.

\begin{tabular}{|c|c|c|c|c|c|c|c|c|c|}
\hline & $\begin{array}{c}\text { AFLP dataset } \\
\text { excluding } \\
\text { E. tuckeyana } \\
\text { (4 primer pairs) }\end{array}$ & $\begin{array}{c}\text { ANA + LAM } \\
\text { (4 primers } \\
\text { pairs })\end{array}$ & $\begin{array}{c}\text { APH } \\
\text { (3 primer } \\
\text { pairs) }\end{array}$ & $\begin{array}{c}\text { ATR+BRA } \\
\text { (3 primer } \\
\text { pairs) }\end{array}$ & $\begin{array}{c}\text { BOU } \\
\text { (3 primer } \\
\text { pairs) }\end{array}$ & $\begin{array}{c}\text { LAM } \\
\text { (4 primer } \\
\text { pairs })\end{array}$ & $\begin{array}{c}\text { PIS } \\
\text { (3 primer } \\
\text { pairs) }\end{array}$ & $\begin{array}{c}\text { REG + } \\
\text { PED } \\
\text { ( } 4 \text { primer } \\
\text { pairs) }\end{array}$ & $\begin{array}{c}\text { TUC } \\
\text { (4 primer } \\
\text { pairs) }\end{array}$ \\
\hline$K=1$ & - & - & - & - & - & - & - & - & - \\
\hline$K=2$ & 0.28 & 622.13 & 0.20 & 243.82 & 14.16 & 0.01 & 167.68 & 291.47 & 14.06 \\
\hline$K=3$ & 1.37 & 1.16 & 0.14 & 1.42 & 168.73 & 1.26 & 1.86 & 19.86 & 0.69 \\
\hline$K=4$ & 1.51 & 11.13 & 0.50 & - & 1.40 & 122.81 & 2.21 & 2.43 & 24.8 \\
\hline$K=5$ & 0.08 & 1.02 & - & & 1.44 & 0.97 & - & 1.24 & 0.03 \\
\hline$K=6$ & 1.81 & 2.81 & & & 0.31 & 0.55 & & 0.37 & 1.18 \\
\hline$K=7$ & 61.04 & 20.41 & & & - & 0.31 & & 0.18 & 1.04 \\
\hline$K=8$ & 0.59 & 0.84 & & & & 0.47 & & 3.16 & 2.99 \\
\hline$K=9$ & 4.26 & 0.17 & & & & - & & 0.38 & 0.07 \\
\hline$K=10$ & 0.37 & & & & & & & - & - \\
\hline$K=11$ & 4.55 & & & & & & & & \\
\hline$K=12$ & 0.58 & & & & & & & & \\
\hline$K=13$ & 6.15 & & & & & & & & \\
\hline$K=14$ & 9.96 & & & & & & & & \\
\hline$K=15$ & - & & & & & & & & \\
\hline
\end{tabular}


Table 4. Analyses of molecular variance (AMOVA) with Euclidean pairwise distances of AFLP markers, using 346 (4 primer pairs) or 249 (3 primer pairs) individuals. In all cases $P$-values of $\phi_{\mathrm{ST}}$ are $<0.0001$. d.f. $=$ degrees of freedom.

\begin{tabular}{|c|c|c|c|c|c|c|}
\hline & & d.f. & Sum of squares & $\begin{array}{c}\text { Variance } \\
\text { components }\end{array}$ & $\%$ of variation & $\phi_{\mathrm{ST}}$ \\
\hline \multirow[t]{2}{*}{ E. aphylla* } & Among populations & 2 & 30.54 & 2.86 & 32.76 & \multirow[t]{2}{*}{0.33} \\
\hline & Within populations & 7 & 39.67 & 5.67 & 67.24 & \\
\hline \multirow[t]{2}{*}{ E. berthelotii } & Among populations & 2 & 46.06 & 3.57 & 31.80 & \multirow[t]{2}{*}{0.32} \\
\hline & Within populations & 10 & 76.55 & 7.65 & 68.20 & \\
\hline \multirow[t]{2}{*}{ E. bourgaeana* } & Among populations & 6 & 141.83 & 5.37 & 69.28 & \multirow[t]{2}{*}{0.69} \\
\hline & Within populations & 21 & 50.07 & 2.38 & 30.72 & \\
\hline \multirow[t]{3}{*}{ E. bourgaeana* by structure groups } & Among groups & 2 & 105.65 & 4.97 & 54.49 & \multirow{3}{*}{0.74} \\
\hline & Among populations & 4 & 36.17 & 1.77 & 19.38 & \\
\hline & Within populations & 21 & 50.07 & 2.38 & 26.13 & \\
\hline \multirow[t]{3}{*}{ E. bourgaeana* by islands } & Among groups & 1 & 51.94 & 3.91 & 54.45 & \multirow{3}{*}{0.8} \\
\hline & Among populations & 4 & 36.17 & 2.09 & 29.10 & \\
\hline & Within populations & 17 & 20.07 & 1.18 & 16.45 & \\
\hline \multirow[t]{2}{*}{ E. lamarckii } & Among populations & 9 & 242.12 & 4.43 & 38.53 & \multirow[t]{2}{*}{0.38} \\
\hline & Within populations & 35 & 247.30 & 7.06 & 61.47 & \\
\hline \multirow[t]{2}{*}{ E. pedroi } & Among populations & 1 & 15.51 & 3.69 & 69.21 & \multirow[t]{2}{*}{0.69} \\
\hline & Within populations & 6 & 9.87 & 1.64 & 30.79 & \\
\hline \multirow[t]{2}{*}{ E. piscatoria } & Among populations & 4 & 82.75 & 3.85 & 37.66 & \multirow[t]{2}{*}{0.38} \\
\hline & Within populations & 14 & 89.35 & 6.38 & 62.34 & \\
\hline \multirow[t]{2}{*}{ E. regis-jubae } & Among populations & 7 & 169.01 & 4.33 & 33.08 & \multirow[t]{2}{*}{0.33} \\
\hline & Within populations & 21 & 184.17 & 8.77 & 66.92 & \\
\hline \multirow[t]{2}{*}{ E. regis-jubae + E. pedroi } & Among populations & 9 & 244.72 & 5.49 & 43.30 & \multirow[t]{2}{*}{0.43} \\
\hline & Within populations & 27 & 194.03 & 7.19 & 56.70 & \\
\hline \multirow[t]{3}{*}{ E. regis-jubae + E. pedroi by structure groups } & Among groups & 1 & 83.31 & 4.39 & 28.83 & \multirow{3}{*}{0.53} \\
\hline & Among populations & 8 & 161.41 & 3.66 & 24.03 & \\
\hline & Within populations & 27 & 194.03 & 7.19 & 47.14 & \\
\hline \multirow{2}{*}{ E. regis-jubae + E. pedroi by islands or mainland enclaves } & Among groups & 4 & 169.104 & 3.37 & 25.92 & \multirow[t]{2}{*}{0.45} \\
\hline & Among populations & 5 & 75.62 & 2.46 & 18.88 & \\
\hline
\end{tabular}


Within populations

Among populations

Within populations
27
194.03

113.79

100.55
55.20

$41.07 \quad 0.41$

58.93 